\title{
Molecular analysis of the distribution and phylogeny of dissimilatory adenosine-5'-phosphosulfate reductase-encoding genes (aprBA) among sulfur- oxidizing prokaryotes
}

\author{
Birte Meyer and Jan Kuevert
}

Correspondence

Jan Kuever

kuever@mpa-bremen.de

Received 21 March 2007

Revised 15 June 2007

Accepted 25 June 2007
Max-Planck-Institute for Marine Microbiology, Celsiusstrasse 1, D-28359 Bremen, Germany

\begin{abstract}
Dissimilatory adenosine-5'-phosphosulfate (APS) reductase (AprBA) is a key enzyme of the dissimilatory sulfate-reduction pathway. Homologues have been found in photo- and chemotrophic sulfur-oxidizing prokaryotes (SOP), in which they are postulated to operate in the reverse direction, oxidizing sulfite to APS. Newly developed PCR assays allowed the amplification of $92-93 \%(2.1-2.3 \mathrm{~kb})$ of the APS reductase locus aprBA. PCR-based screening of 116 taxonomically divergent $\mathrm{SOP}$ reference strains revealed a distribution of aprBA restricted to photo- and chemotrophs with strict anaerobic or at least facultative anaerobic lifestyles, including Chlorobiaceae, Chromatiaceae, Thiobacillus, Thiothrix and invertebrate symbionts. In the AprBAbased tree, the SOP diverge into two distantly related phylogenetic lineages, Apr lineages I and II, with the proteins of lineage II (Chlorobiaceae and others) in closer affiliation to the enzymes of the sulfate-reducing prokaryotes (SRP). This clustering is discordant with the dissimilatory sulfite reductase (DsrAB) phylogeny and indicates putative lateral aprBA gene transfer from SRP to the respective SOB lineages. In support of lateral gene transfer (LGT), several beta- and gammaproteobacterial species harbour both aprBA homologues, the DsrAB-congruent 'authentic' and the SRP-related, LGT-derived gene loci, while some relatives possess exclusively the SRP-related apr genes as a possible result of resident gene displacement by the xenologue. The two-gene state might be an intermediate in the replacement of the resident essential gene. Collected genome data demonstrate the correlation between the AprBA tree topology and the composition/arrangement of the apr gene loci (occurrence of qmoABC or aprM genes) from SRP and SOP of lineages I and II. The putative functional role of the SRP-related APS reductases in photo- and chemotrophic SOP is discussed.
\end{abstract}

†Present Address: Bremen Institute for Materials Testing, Paul-FellerStrasse 1, D-28199 Bremen, Germany.

Abbreviations: APAT, adenylylsulfate: phosphate adenylyltransferase; APS, adenosine-5'-phosphosulfate; DGGE, denaturing gradient gel electrophoresis; DG-DGGE, double-gradient DGGE; LGT, lateral gene transfer; SAOR, sulfite : acceptor oxidoreductase; SDR, sulfur dioxygenase; SOB, sulfur-oxidizing bacteria; SOP, sulfur-oxidizing prokaryotes; SOR, sulfide: quinone oxidoreductase; SRP, sulfate-reducing prokaryotes.

The GenBank/EMBL/DDBJ accession numbers for the aprBA and $16 \mathrm{~S}$ rRNA sequences of the species examined in this study are EF641902EF641963 and EF675611-EF675615, respectively.

A supplementary table of the presence of genes encoding dissimilatory sulfite reductase and its functionally associated proteins in genome sequences of $\mathrm{SOB}$, and two supplementary figures showing a phylogenetic consensus tree based on 16S rRNA gene sequences from the apr-containing SOB reference strains, and an AprB and AprA alignment showing indels among selected representatives of the major phylogenetic SOB lineages, are available with the online version of this paper.

\section{INTRODUCTION}

Microbial sulfur oxidation is a key process in the oxidative half of the sulfur cycle in soil and water, and dominates as the major reaction, especially in extreme environments such as volcanic hot springs, solfataras and deep-sea hydrothermal vents. Reduced inorganic sulfur compounds such as sulfide, polysulfides, sulfur, sulfite, thiosulfate and various polythionates can serve as electron donors for the energy-generating systems in many photo- and chemotrophic species of the domain Bacteria, whereas this metabolic capability is restricted in the domain Archaea to representatives of the thermoacidophilic order Sulfolobales (Brune, 1995; Brüser et al., 2000; Friedrich, 1998; Huber \& Prangishvili, 2000; Nelson \& Fisher, 1995; Overmann \& Garcia-Pichel, 2001). The sulfur-oxidizing prokaryotes (SOP) are phylogenetically and physiologically diverse, differing in their abilities to utilize the various reduced sulfur compounds. As a consequence, the enzymic 
pathways used for dissimilatory sulfur oxidation have been found to be widely variable and may involve different intermediates (Brune, 1995; Brüser et al., 2000; Friedrich, 1998; Friedrich et al., 2001; Kletzin et al., 2004; Nelson \& Fisher, 1995). The oxidation of sulfide generally results in the formation of periplasmic and extracellular sulfur globules mediated by the activity of the ubiquitous enzyme sulfide: quinone oxidoreductase (SQR) (Griesbeck et al., 2000; Theissen et al., 2003). Its further oxidation to sulfate has been suggested to be mediated by the reverse-operating enzymes of the sulfate-reduction process, comprising the dissimilatory ATP sulfurylase, adenosine-5' -phosphosulfate (APS) reductase and sulfite reductase, which are ubiquitously present in the sulfate-reducing prokaryotes (SRP). Homologues have been shown to exist in several anoxygenic phototrophic and facultative anaerobic chemotrophic sulfur-oxidizing bacteria (SOB) (Dahl \& Trüper, 1994; Hipp et al., 1997; Taylor, 1994; Trüper \& Fischer, 1982). Experimental evidence is accumulating that the reverse-acting sulfite reductase (DsrAB) and its functionally associated transmembrane redox complex DsrMKJOP are essential for the oxidation of sulfide or intermediately stored sulfur to sulfite (Dahl et al., 2005; Sander et al., 2006). Its subsequent oxidation to sulfate can be mediated by two different enzymes in SOB: (1) the APS reductase (Apr), catalysing the oxidative binding of sulfite to AMP, which generates APS as product; and (2) the sulfite: acceptor oxidoreductase (SAOR), catalysing the AMPindependent oxidation to sulfate without formation of intermediates (Brune, 1995; Brüser et al., 2000; Kappler \& Dahl, 2001). Sulfate is released from APS by the activity either of ATP sulfurylase (Sat) or adenylylsulfate:phosphate adenylyltransferase (APAT). Energy is yielded by substrate phosphorylation, with the former enzyme transferring the AMP moiety of APS onto pyrophosphate, which leads to ATP formation, while the latter enzyme uses phosphate for replacement and produces ADP (Brune, 1995; Brüser et al., 2000).

Recent studies have confirmed that the dissimilatory APS reductases (irrespective of metabolic type) consist of two different subunits, which are proposed to form a $1: 1 \alpha \beta$ heterodimeric iron-sulfur flavoenzyme (AprBA). Only the $\alpha$ subunit, AprA, has structural similarity to the flavoprotein subunits of the succinate-dehydrogenase/fumaratereductase family; however, this structural relationship is not reflected in sequence similarity (Fritz et al., 2000, 2002; Schiffer et al., 2006). The encoding genes, aprBA, have been cloned from sulfur-oxidizing Allochromatium vinosum; comparative sequence analysis confirmed their homology to the dissimilatory APS reductase of bacterial and archaeal SRP (Hipp et al., 1997). However, the in vivo role of the reverse APS reductase, compared to that of the SAOR, in the dissimilatory oxidative sulfur metabolism of photoand chemotrophic SOP (Dahl, 1996; Sanchez et al., 2001) and its functional linkage to the photosynthetic and respiratory electron transport chain are still unresolved. For SRP, there is increasing evidence that the Qmo redox complex, consisting of one membrane-integral ( $\mathrm{QmoC})$ and two cytoplasmic (QmoAB) proteins, acts as a menaquinol/APS reductase oxidoreductase (Haveman et al., 2004; Pires et al., 2003).

Previous phylogenetic analyses of enzymes of the sulfatereduction pathway (Apr and Dsr) have been restricted to SRP, and have revealed that multiple lateral gene transfer (LGT) events have affected their evolutionary path (Friedrich, 2002; Klein et al., 2001) (Meyer \& Kuever, 2007). The aims of this study were (1) the comprehensive molecular investigation of aprBA distribution among SOP by examining 116 representatives of photo- and chemotrophic sulfur-oxidizing Archaea and Bacteria, and (2) the phylogenetic analysis of the AprBA sequences to reveal potential LGTs affecting the SOP and to elucidate the origin and evolution of the sulfite-oxidation process. Accordingly, novel PCR assays were developed that enabled the amplification and direct sequencing of $92-93 \%$ (equivalent to $2.1-2.3 \mathrm{~kb}$ ) of the reverse APS reductase gene region to establish a new aprBA database from the major taxonomic lineages of SOP. The results of this work also provide a framework for future molecular ecological studies to investigate the microbial community of the sulfur cycle by functional gene analysis.

\section{METHODS}

Micro-organisms. The investigated reference strains of photo- and chemotrophic SOB (listed in Table 1) were obtained from the DSMZ (Braunschweig, Germany). Genomic DNA of Chlorobiaceae and several Chromatiaceae were received from the culture collection of J. Imhoff (University of Kiel) Extracted genomic DNAs of invertebrate tissues were provided by N. Dubilier, Max-PlanckInstitute for Marine Microbiology, (Inanidrilus spp., Bathymodiolus azoricus and Bathymodiolus brevior), A. D. Nussbauer, University of Vienna, (Riftia pachyptila, Bathymodiolus thermophilus, Calyptogena magnifica and Oasisia sp.) and C. Borowski, Max-Planck-Institute for Marine Microbiology, (Ifremeria nautilei). Harvested cells of Beggiatoa spp., Aquaspirillum spp., Macromonas bipunctata strain D-408 and Spirochaeta spp. were received from G. Dubinina, Winogradsky Institute of Microbiology. The SOB strain 'manganese crust' was isolated from enrichment cultures of sediment and seawater samples from the Caribbean Sea (Caribflux project, SO-154).

DNA isolation. Genomic DNA from the investigated reference strains was obtained by applying the DNAeasy kit (Qiagen) or the NUCLEOBOND kit (Macherey-Nagel) according to the manufacturers' instructions. The DNA concentration and quality were estimated spectrophotometrically, while its integrity was examined visually by gel electrophoresis on $0.8 \%(\mathrm{w} / \mathrm{v})$ agarose gels run in $1 \times$ Tris/borate/EDTA (TBE) buffer and followed by ethidium bromide staining $\left(0.5 \mu \mathrm{g} \mathrm{ml}^{-1}\right)$.

PCR amplification of aprBA and 16S rRNA genes. The forward primers AprB-1-FW and AprB-3-FW (with different target sites in the $a p r B$ gene) were used in combination with the reverse primer AprA5-RV for amplification of a $1.2-1.3 \mathrm{~kb}$ and a $1.2-1.1 \mathrm{~kb}$ aprBA gene fragment, respectively. The forward primer AprA-1-FW was combined with the reverse primers AprA-9-RV or AprA-10-RV (identical target site in the aprA gene), which yielded a $1.4 \mathrm{~kb}$ aprA amplicon from the 5 '-terminal region of $a p r A$. The $a p r B A$ and $a p r A$ amplicons 
Table 1. PCR amplification results for aprBA gene fragments from genomic DNA of sulfur-oxidizing reference strains

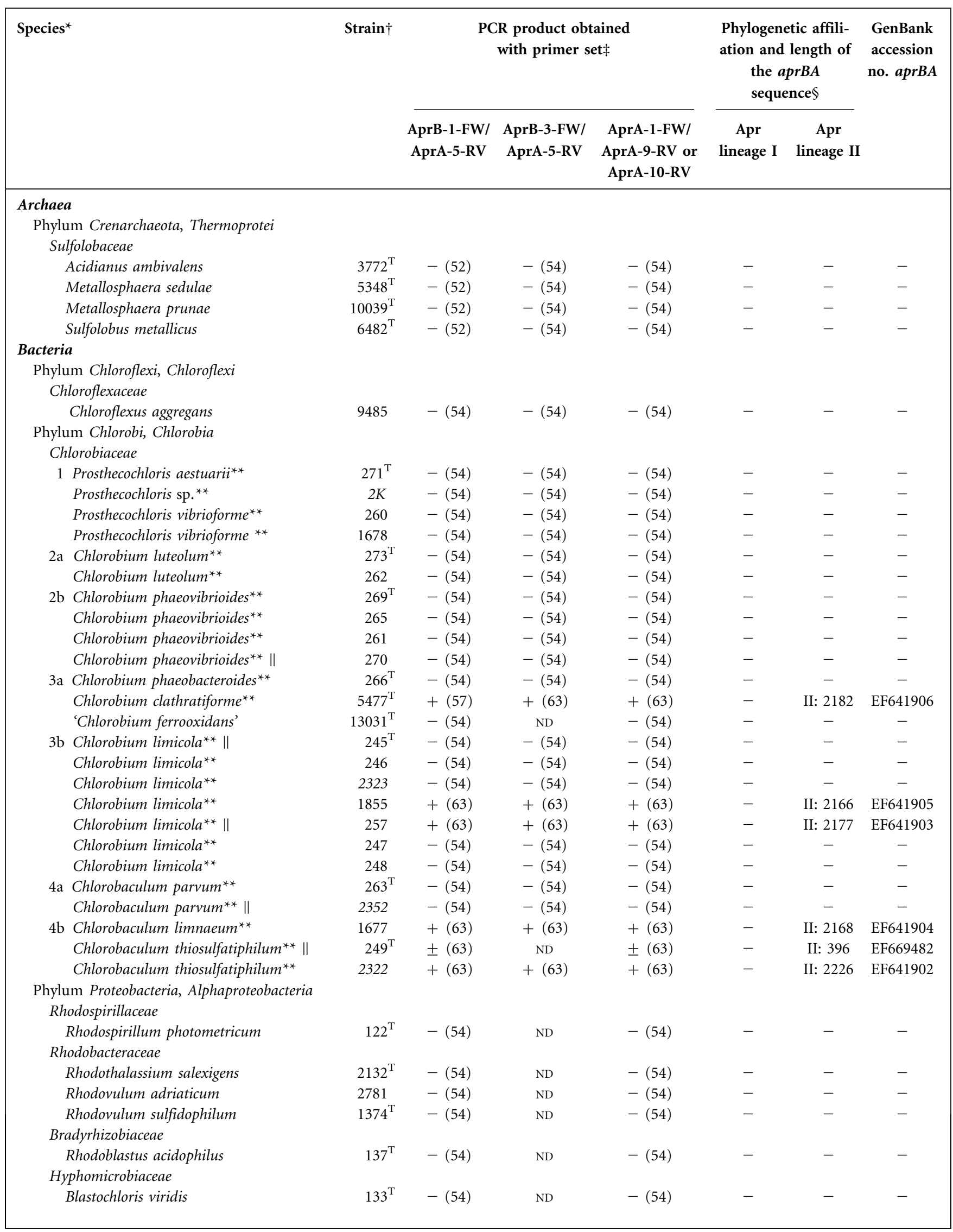


Table 1. cont.

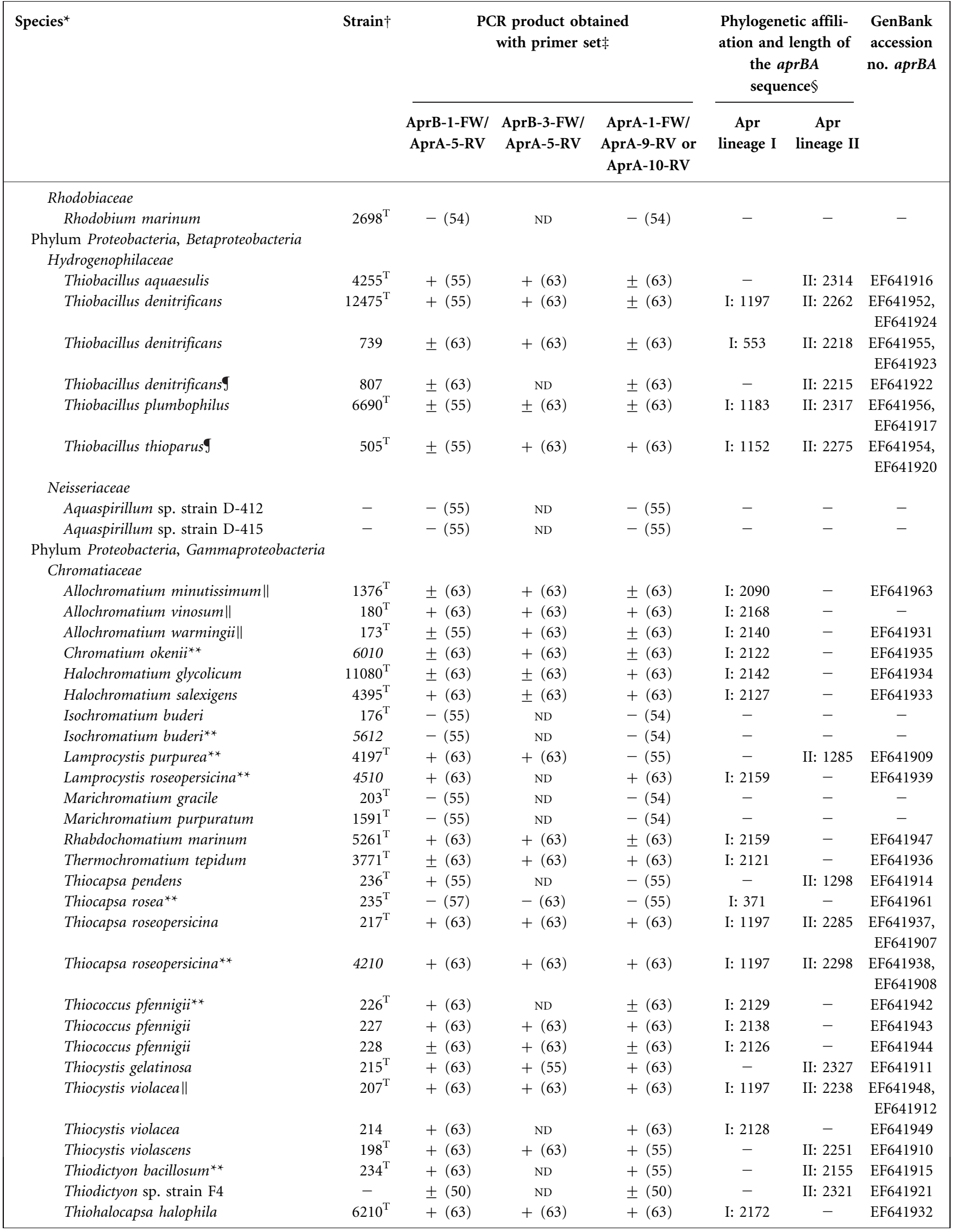


Table 1. cont.

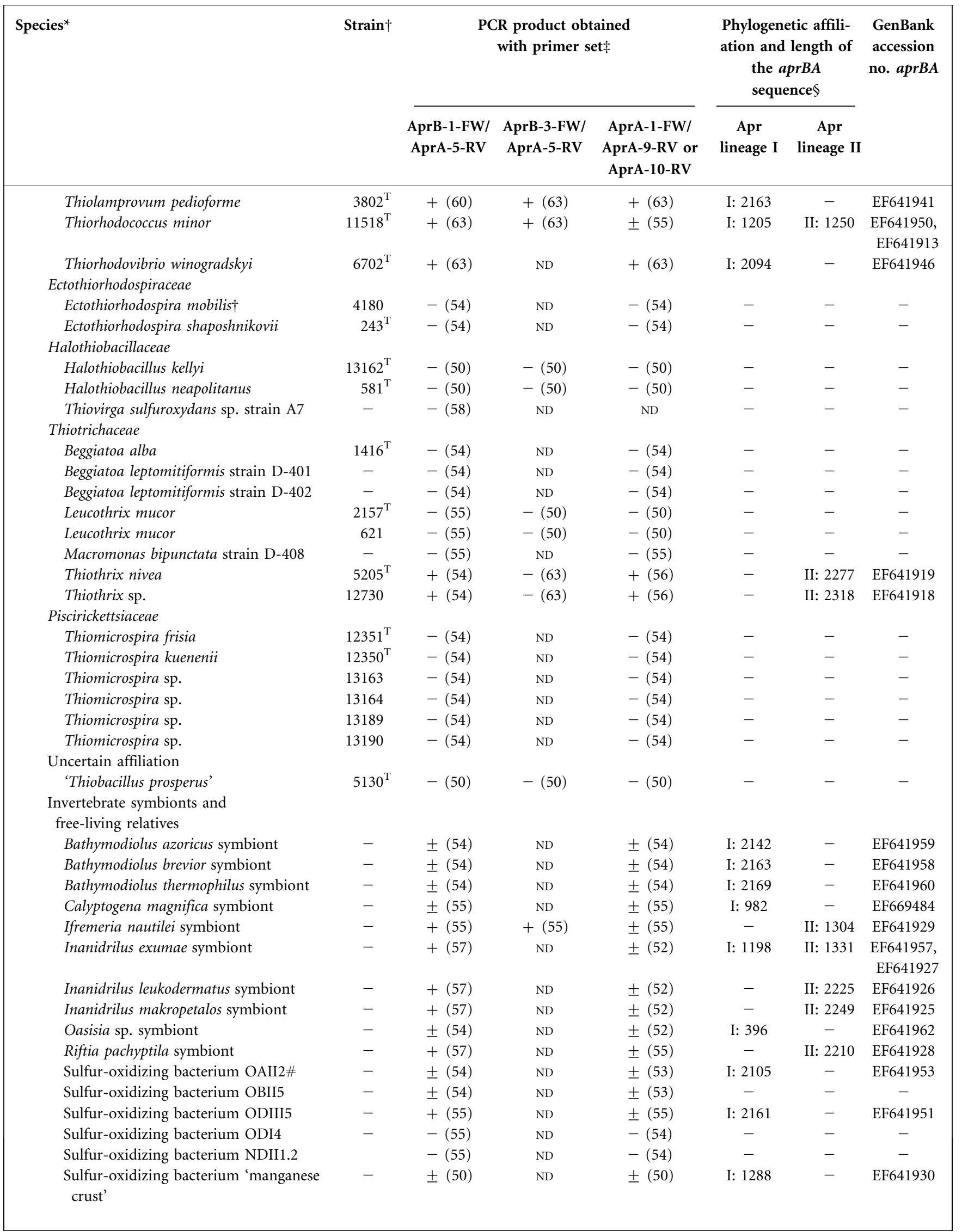


Table 1. cont.

\begin{tabular}{|c|c|c|c|c|c|c|c|}
\hline \multirow[t]{2}{*}{ Species* } & \multirow[t]{2}{*}{ Strain $\dagger$} & \multicolumn{3}{|c|}{$\begin{array}{l}\text { PCR product obtained } \\
\text { with primer set } \ddagger\end{array}$} & \multicolumn{2}{|c|}{$\begin{array}{l}\text { Phylogenetic affili- } \\
\text { ation and length of } \\
\text { the } a p r B A \\
\text { sequence } \$\end{array}$} & \multirow[t]{2}{*}{$\begin{array}{l}\text { GenBank } \\
\text { accession } \\
\text { no. } \text { aprBA }\end{array}$} \\
\hline & & $\begin{array}{l}\text { AprB-1-FW/ } \\
\text { AprA-5-RV }\end{array}$ & $\begin{array}{l}\text { AprB-3-FW/ } \\
\text { AprA-5-RV }\end{array}$ & $\begin{array}{l}\text { AprA-1-FW/ } \\
\text { AprA-9-RV or } \\
\text { AprA-10-RV }\end{array}$ & $\begin{array}{c}\text { Apr } \\
\text { lineage I }\end{array}$ & $\begin{array}{c}\text { Apr } \\
\text { lineage II }\end{array}$ & \\
\hline \multicolumn{8}{|c|}{$\begin{array}{l}\text { Phylum Proteobacteria, Epsilonproteobacteria } \\
\text { Helicobacteraceae }\end{array}$} \\
\hline $\begin{array}{l}\text { Sulfurimonas denitrificans } \\
\text { Phylum Spirochaeta, Spirochaete } \\
\text { Spirochaetaceae }\end{array}$ & $1251^{\mathrm{T}}$ & $-(54)$ & ND & $-(54)$ & - & - & - \\
\hline Spirochaeta sp. strain $\mathrm{P}$ & - & $-(55)$ & ND & $-(55)$ & - & - & - \\
\hline
\end{tabular}

*Taxonomic classification of investigated SRP species according to the Taxonomic outline of the prokaryotes, Bergey's Manual of Systematic Bacteriology, 2nd edition, release 5.0, May 2004 (http://dx.doi.org/10.1007/bergeysoutline); genomic DNA of sulfur-oxidizing reference strains marked with ${ }^{* *}$ were received from J. Imhoff's laboratory (Kiel, Germany).

$\nmid \mathrm{DSMZ}$ strain numbers of investigated species (Imhoff laboratory internal numbers in italic type); -, not deposited in a culture collection; T, type strain. $\ddagger$ PCR amplification results with the respective primer pair: + , correct-sized amplicon without by-products; \pm , correct-sized amplicon with byproducts; -, no amplicon obtained; ND, PCR amplification not determined. The initial PCR annealing temperature $\left({ }^{\circ} \mathrm{C}\right)$ is given in parentheses. §Length of assembled aprBA gene fragment PCR product and phylogenetic assignment of the deduced AprBA sequence to the Apr lineages I and II. \| Proposed presence of dissimilatory APS reductase in respective species based on enzyme activity assay (see Dahl \& Trüper, 1994, and references therein).

SProposed presence of dissimilatory APS reductase in respective species based on enzyme activity assay (see Taylor, 1994, and references therein). \#Proposed presence of dissimilatory APS reductase in respective species based on enzyme activity assay (see Kuever et al., 2002).

$\dagger \dagger$ Uncertain taxonomic classification (synonym Ectothiorhodospira marismortui).

overlap in sequence by $\sim 390 \mathrm{bp}$ (corresponding to nucleotide positions 3471-3859 in the sat-aprMBA operon of Allochromatium vinosum; Table 2).

PCR assays were performed with the REDTaq DNA polymerase kit (Sigma-Aldrich). Reaction mixtures ( $50 \mu \mathrm{l}$ total volume) contained $5 \mu \mathrm{l} 10 \times \mathrm{REDTaq}$ PCR reaction buffer (with $11 \mathrm{mM} \mathrm{MgCl}_{2}$ ), $5 \mu \mathrm{l}$ $10 \times$ BSA solution $\left(3 \mathrm{mg} \mathrm{ml}^{-1}\right), 200 \mu \mathrm{M}$ deoxynucleoside triphosphates (dNTPs) mixture, $1 \mu \mathrm{M}$ of each primer and 10-100 ng genomic DNA as template (water was used as a negative control in all PCR amplifications). PCR amplification was performed in a thermocycler (Eppendorf) with an initial denaturation step of $95{ }^{\circ} \mathrm{C}$ for $5 \mathrm{~min}$ followed by the addition of $2.5 \mathrm{U}$ REDTaq DNA polymerase to each PCR assay (hot start PCR). Subsequently, a 'touchdown' thermal profile was performed ( 35 cycles in total): $95{ }^{\circ} \mathrm{C}$ for $60 \mathrm{~s}$ (denaturation), $63{ }^{\circ} \mathrm{C}$ for $90 \mathrm{~s}$ ('touchdown': the annealing temperature was lowered at every cycle of the first 20 cycles by $0.5{ }^{\circ} \mathrm{C}$ to a final temperature of $53{ }^{\circ} \mathrm{C}$, after which 15 additional cycles were carried out) and $72{ }^{\circ} \mathrm{C}$ for $120 \mathrm{~s}$ (elongation). Amplification was completed by a final elongation step at $72{ }^{\circ} \mathrm{C}$ for $10 \mathrm{~min}$. The initial annealing temperature of the 'touchdown' was altered in a range between 63 and $55{ }^{\circ} \mathrm{C}$ to optimize the amplification results.

16S rRNA gene fragments were amplified using the primer sets GM3F/GM4R and GM5F-GC clamp/907R [for subsequent denaturing gradient gel electrophoresis (DGGE) analysis] with the PCR conditions described elsewhere (Muyzer et al., 1995).

Double-gradient (DG) DGGE analysis of PCR-amplified 165 rRNA gene fragments. DG-DGGE was applied to improve the quality of $16 \mathrm{~S}$ rDNA band separation and resolution. An acrylamide gradient from 6 to $8 \%$ acrylamide/bisacrylamide stock solution, $37.5: 1(\mathrm{v} / \mathrm{v})($ Bio-Rad), was superimposed over a collinear denaturant gradient from 20 to $70 \%$ of denaturant [100\% denaturant corresponds to $7 \mathrm{M}$ urea and $40 \%$ formamide (v/v), deionized with AG501-X8 mixed bed resin (Bio-Rad)]. Gradients were formed using a Bio-Rad Gradient Former model 385. PCR samples were applied to the gels in aliquots of $20 \mu \mathrm{l}$ per lane. Further analysis was performed as described elsewhere (Muyzer et al., 1995) using the D-CODE and D-GENE systems (Bio-Rad) for electrophoresis runs in $1 \times$ Tris/ acetate/EDTA (TAE) buffer at $60{ }^{\circ} \mathrm{C}$ for $3.5 \mathrm{~h}$ at $200 \mathrm{~V}$. After staining with ethidium bromide $\left(0.5 \mu \mathrm{g} \mathrm{ml}^{-1}\right)$, DNA bands were visualized on a UV transillumination table (Biometra), excised from the polyacrylamide gel, eluted in $50 \mu \mathrm{l}$ Tris/ $\mathrm{HCl}, \mathrm{pH} 8.0$, and reamplified using the original PCR conditions and primer pair without a GC clamp.

Cloning of PCR products. The aprBA and 16S rRNA amplicons were ligated into pCR2.1-TOPO vectors (TOPO TA cloning systems; Invitrogen) and transformed into chemically competent Escherichia coli TOP10 cells as recommended by the manufacturer. Clone plasmids were screened for correct-sized inserts by PCR amplification followed by RFLP analysis of the amplicons. Cloned plasmids with different digestion patterns were selected for sequencing and recovered with the QIAprep spin kit (Qiagen).

Nucleotide sequencing. The aprBA, aprA and $16 \mathrm{~S}$ rDNA PCR products of the expected sizes were purified using QIAquick PCR purification, the QIAquick gel extraction kit (Qiagen) or the 
Table 2. PCR primers utilized for amplification of the aprBA and aprA gene fragments

\begin{tabular}{|llcl|}
\hline Primer & \multicolumn{1}{c|}{ Sequence $\left(\mathbf{5}^{\prime} \rightarrow \mathbf{3}^{\prime}\right)^{\star}$} & Primer binding site $\dagger$ & \multicolumn{1}{c|}{ Reference } \\
\hline AprB-1-FW & TGC GTG TAY ATH TGY CC & $2653-2669$ & $\ddagger$ \\
AprB-3-FW & ACM WGT GCT GGG AGT GCT AC & $2726-2745$ & This study \\
AprA-1-FW & TGG CAG ATC ATG ATY MAY GG & $3471-3490$ & $\ddagger$ \\
AprA-5-RV & GCG CCA ACY GGR CCR TA & $3843-3859$ & $\ddagger$ \\
AprA-9-RV & CKG WAG TAG TAR CCS GGS YA & $4811-4831$ & This study \\
AprA-10-RV & CKG WAG TAG WAR CCR GGR TA & $4811-4831$ & $\ddagger$ \\
& & & \\
\hline
\end{tabular}

${ }^{*}$ Degenerate positions are in bold type.

$\dagger$ Corresponding nucleotide positions of the sat-aprMBA operon of Allochromatium vinosum (GenBank accession no. U84759).

¥Meyer \& Kuever (2007).

Perfectprep gel cleanup sample kit (Eppendorf,), following the suppliers' recommendations. All PCR products were sequenced directly in both directions using the respective amplification primers and the ABI BigDye terminator cycle sequencing kit (Applied Biosystems). Sequencing reactions were run on an ABI PRISM 3100 Genetic Analyzer (Applied Biosystems).

Sequence analysis tools and phylogenetic tree inference. The nucleotide sequence data for the aprBA and aprA amplicons were assembled (2.1-2.3 kb total length) and manually corrected using the BioEdit (version 7.0.5) sequence alignment editor (http:// www.mbio.ncsu.edu/BioEdit/BioEdit.html). BLAST searches for homologues (AprBA and DsrAB) were performed at the NCBI website (http://www.ncbi.nlm.nih.gov/BLAST/). Searches on the preliminary sequence data of ongoing SOB and SRP genome sequencing projects were performed at The Institute for Genomic Research website (http://www.tigr.org) and at the US Department of Energy (DOE) Joint Genome Institute website (http://img.jgi.doe.gov/cgi-bin/pub/ main.cgi). The AprBA and DsrAB sequences were aligned by using the web server Tcoffee@igs (http://igs-server.cnrs-mrs.fr/Tcoffee/). The AprBA and DsrAB datasets were phylogenetically analysed with the tree inference methods included in the ARB software package (http://www.arb-home.de). Alignment regions of insertions and deletions (indels) were not considered. Unrooted phylogenetic trees were calculated based on two AprBA datasets of 379 and 701, and a DsrAB dataset of 740 compared amino acid positions, using the ARB implemented program package (distance matrix, Fitch analysis; maximum-parsimony, ProtPars; maximum-likelihood, ProML) and the PhyML program (maximum-likelihood method; http:// atgc.lirmm.fr/phyml). Maximum-likelihood trees were constructed using the Whelan and Goldman (WAG) or Jones, Taylor and Thornton (JTT) amino acid substitution model matrices. The robustness of inferred trees was tested by bootstrap analysis with 100 resamplings using the PhyML program.

Prediction of potential promoters, termination sites and gene arrangement in operons was performed using the web versions FGENESB, BPROM and BTERM of the Softberry program package (http:// www.softberry.com/berry.phtml). Secondary structure analysis and transmembrane helix prediction were done using programs available at http://us.expasy.org/tools/\#secondary.

Southern blot analysis. Identical amounts of genomic DNA $(5 \mu \mathrm{g})$ from sulfur-oxidizing and sulfate-reducing bacteria (Table 3 ) were digested at $37{ }^{\circ} \mathrm{C}$ with HindIII and EcoRI overnight, precipitated by ethanol, electrophoresed on $0.8 \% 1 \times$ TAE buffer at $100 \mathrm{~V}$ for $3 \mathrm{~h}$, transferred to positively charged nylon membranes (Hybond-N + filter, Amersham) by capillary neutral transfer and immobilized by
UV cross-linking (Transilluminator; Biometra). The aprA gene DNA probes $\left(0.4 \mathrm{~kb}\right.$ in length) were radioactively labelled with $\left[\alpha-{ }^{32} \mathrm{P}\right] \mathrm{dCTP}$ by the random-priming method using the HexaLabel DNA labelling kit (MBI Fermentas) according to the manufacturer's instructions. The membranes were placed into glass hybridization bottles and prehybridized in $5 \times \mathrm{SSC}(1 \times \mathrm{SSC}$ is $0.15 \mathrm{M} \mathrm{NaCl}, 0.015 \mathrm{M}$ sodium citrate, pH 8.0), $50 \%$ formamide, $0.1 \%$ sarcosyl, $7 \%$ SDS, $50 \mathrm{mM}$ phosphate buffer, $\mathrm{pH} 7.0$, and $2 \%$ casein ('Church' hybridization solution) at $50{ }^{\circ} \mathrm{C}$ for $1 \mathrm{~h}$ in a hybridization oven (Biometra). Subsequently, a freshly denaturated, labelled DNA probe was added to the prehybridization solution followed by incubation for $12-16 \mathrm{~h}$ at $50{ }^{\circ} \mathrm{C}$ under slow-speed rotation. The membranes were washed twice at $50{ }^{\circ} \mathrm{C}$ for $30 \mathrm{~min}$ in $0.1 \times \mathrm{SSC} / 0.1 \%$ SDS, exposed to PhosphorImaging screen cassettes (Molecular Dynamics), scanned with a Typhoon Variable Mode Imager and processed with ImageQuant software (Amersham). The membranes were stripped by two incubations for $15 \mathrm{~min}$ in probestripping solution (consisting of $0.4 \mathrm{M} \mathrm{NaOH}$ and $0.1 \%$ SDS) at $37{ }^{\circ} \mathrm{C}$ under permanent agitation and reprobed, starting from the prehybridization step of the hybridization procedure.

\section{RESULTS}

\section{Amplification of aprBA genes by PCR from SOB}

In this study, 116 archaeal or bacterial, photo- or chemolithotrophic reference strains were investigated for the presence of aprBA genes. Previous studies have reported the association of invertebrates with a single thiotrophic symbiont phylotype (Blazejak et al., 2006; Bright \& Giere, 2005; Cavanaugh et al., 2001; Nelson \& Fisher, 1995), which is supported by the single Apr sequences obtained from the investigated species (except Inanidrilus exumae). The results of the PCR-based survey are summarized in Table 1 and demonstrate the high species diversity coverage of the primers. In general, the four different primer sets yielded correct-sized PCR products when higher annealing temperatures $\left(>55{ }^{\circ} \mathrm{C}\right)$ were applied in the assays. However, in some cases (e.g. invertebrate symbionts) the annealing temperature had to be lowered (from 55 to $50{ }^{\circ} \mathrm{C}$ ) to obtain a sufficient amount of apr amplicons for direct sequencing. The comparison of the primer sequences to newly available genomic aprBA sequences (e.g. Candidatus Ruthia magnifica 
Table 3. Determination of apr gene locus number in SOB

Cloning assay results for the aprBA amplicons from SOB species for which direct sequencing failed are shown; the potential presence of contaminants in the investigated SOB cultures was checked by cloning and DGGE analysis of PCR-amplified 16S rRNA gene fragments.

\begin{tabular}{|c|c|c|c|c|}
\hline \multirow[t]{2}{*}{ Species } & \multirow[t]{2}{*}{ DSM $^{*}$} & \multirow{2}{*}{$\begin{array}{c}\text { Gene locus number according } \\
\text { to sequence analysis of cloned } \\
\text { aprBA amplicons } \dagger \\
\text { AprB-1-FW or } \\
\text { AprB-3-FW/AprA-5-RV } \S\end{array}$} & \multicolumn{2}{|c|}{$\begin{array}{l}\text { DGGE analysis and cloning assay results } \\
\text { of } 16 S \text { rRNA gene amplicons } \ddagger\end{array}$} \\
\hline & & & GM5F-GC clamp/907R $\$$ & GM3F/GM4R $\$$ \\
\hline \multicolumn{5}{|l|}{ Gammaproteobacteria } \\
\hline Thiocapsa roseopersicina & 217 & 2 (Apr lineages I and II) & Four DGGE bandsII & ND \\
\hline Thiocapsa roseopersicina & $4210^{\star *}$ & $2($ Apr lineages I and II) & Two DGGE bands॥ & ND \\
\hline Thiocystis violacea & 207 & 2 (Apr lineages I and II) & $\begin{array}{l}\text { Two DGGE bands: seq. } \\
\text { nearly identical to } \\
\text { reference strain }\end{array}$ & $\begin{array}{l}\text { Two seq. nearly identical to } \\
\text { reference strain }\end{array}$ \\
\hline Thiorhodococcus minor & 11518 & 2 (Apr lineages I and II) & $\begin{array}{l}\text { Two DGGE bands: seq. } \\
\text { nearly identical to } \\
\text { reference strain }\end{array}$ & $\begin{array}{l}\text { Two seq. nearly identical to } \\
\text { reference strain }\end{array}$ \\
\hline \multicolumn{5}{|l|}{ Invertebrate symbionts } \\
\hline Inanidrilus exumae & - & 2 (Apr lineages I and II) & Two DGGE bandsII & ND \\
\hline \multicolumn{5}{|l|}{ Betaproteobacteria } \\
\hline Thiobacillus denitrificans & 12475 & 2 (Apr lineages I and II) & $\begin{array}{l}\text { One DGGE band: seq. } \\
\text { identical to reference strain }\end{array}$ & One seq. identical to reference strain \\
\hline Thiobacillus denitrificans & 739 & 2 (Apr lineages I and II) & $\begin{array}{l}\text { One DGGE band: seq. } \\
\text { identical to reference strain }\end{array}$ & ND \\
\hline Thiobacillus plumbophilus & 6690 & 2 (Apr lineages I and II) & $\begin{array}{l}\text { One DGGE band: seq. } \\
\text { identical to reference strain }\end{array}$ & One seq. identical to reference strain \\
\hline Thiobacillus thioparus & 505 & 2 (Apr lineages I and II) & $\begin{array}{l}\text { One DGGE band: seq. } \\
\text { identical to reference strain }\end{array}$ & ND \\
\hline
\end{tabular}

${ }^{\star}$ Cultures obtained from culture collection of J. Imhoff (laboratory internal numbers in italic type) are marked with ${ }^{\star *}$; - , not deposited in a culture collection.

$\dagger$ Phylogenetic assignment of AprBA sequences to Apr lineages I and II in parentheses.

¥Abbreviations: ND, 16S rDNA amplicon cloning assays of respective SOB species were not performed; seq., sequence(s).

§Primer sets used to generate amplicons. For primer sets GM5F/907R and GM3F/GM4R, see Muyzer et al. (1995).

IINo pure culture of reference strains according to $16 \mathrm{~S}$ rDNA-based DGGE analysis: besides the sulfur-oxidizing reference strain, additional $16 \mathrm{~S}$ rDNA sequence(s) indicated the presence of non-sulfur-oxidizing species (BLAST search results) in the investigated cultures.

and Olavius algarvensis symbionts) (Newton et al., 2007; Woyke et al., 2006) revealed the presence of single mismatches to the strictly conserved target sites. However, as reported for 16S rRNA-based studies (Kwok et al., 1990; Simsek \& Adnan, 2000), the presence of single mismatches at internal or $5^{\prime}$-end sequence positions in the novel PCR primers did not affect their PCR efficiency. Thus, the absence of apr amplicons most likely reflects the absence of the APS reductase genes in the respective $\mathrm{SOB}$ species. Overall, the occurrence of aprBA genes in SOB seemed to be restricted to most Chromatiaceae species, a few representatives of the Chlorobiaceae, Thiobacillus spp. (Betaproteobacteria), Thiothrix spp. and the sulfur-oxidizing symbionts, including their free-living relatives (Gammaproteobacteria).

\section{Number of apr gene loci in SOB}

Interestingly, direct nucleotide sequencing of aprBA and $a p r A$ amplicons of some SOB species (Table 3) failed due to high levels of sequence ambiguities. Investigation of the genome of Thiobacillus denitrificans ATCC 25259 (Beller et al., 2006) revealed the existence of two apr gene loci of differing sequence. Therefore, the previous SOB species were checked for the presence of multiple apr genes by cloning assays of the aprBA PCR products and subsequent RFLP analysis of the recombinant plasmids. The assays revealed the existence of two aprBA genes of differing sequence in genomic DNA from Thiocapsa roseopersicina (DSM 217 and 4210), Thiocystis violacea and Thiorhodococcus minor, Thiobacillus denitrificans (DSM 12475 and 739), Thiobacillus thioparus and Thiobacillus plumbophilus cultures, and the Gamma-4 symbiont of Inanidrilus exumae (see Table 3). The GM3F/GM4Ramplified 16S rRNA gene fragments of these species were analysed by cloning assays (followed by RFLP analysis), while all investigated SOB cultures were checked by $16 \mathrm{~S}$ rDNAbased DGGE analysis; the results confirmed the absence of putative sulfur-oxidizing, apr-harbouring contaminants in the examined reference strain cultures of this study. 
Unexpectedly, PCR amplification of apr gene fragments was unsuccessful for most studied Chlorobiaceae (see Table 1). Therefore, Southern blot experiments were performed with Chlorobium spp. [subclusters 2a and $3 \mathrm{~b}$ (Imhoff, 2003)] by using different, radioactively labelled aprA probes (Table 4; aprA probe sequence was verified by direct sequencing of an identical non-labelled PCR product). The Southern blot analyses confirmed the results of the PCR assays for the Chlorobiaceae. In addition, the appearance of two distinct hybridization signals with the Thiocapsa roseopersicina-specific probe supported the existence of two aprA genes in Thiocapsa roseopersicina, as suggested by the PCR and cloning assays (Table 1).

\section{Phylogeny of dissimilatory APS reductase of SOB}

The 63 partial (Table 1) and 27 full-length AprBA sequences of sulfur-oxidizing reference strains (from public databases; Table 5) were integrated into the pre-existing AprBA database of SRP species (Meyer \&, 2007). Phylogenetic trees were constructed based on (1) 379 compared positions (sequence data of the aprBA amplicon) (Fig. 1) and (2) 701 compared positions (assembled sequence data of the aprBA and aprA amplicons) (Fig. 2). In contrast to the DsrAB phylogeny, which clearly demonstrates the evolutionary divergence of the proteins from sulfate/sulfite reducers and sulfur oxidizers into two separate clusters (Fig. 3), the AprBA sequences of SOB separated into two distinct lineages, Apr lineages I and II. While the oxidative-operating AprBA proteins of lineage I formed a distinct, DsrAB-congruent cluster of SOB (less than $43.5 \%$ sequence identity to the SRP and affiliated SOB Apr lineage II sequences), the oxidative-operating AprBA proteins of lineage II were DsrAB-discordantly placed in closer affiliation with the reductive-operating enzymes of the SRP, which was indicative of LGT events. Within these major Apr lineages, the SOB taxa clustered consistently with their $16 \mathrm{~S}$ rRNA-gene-based classification into the Chlorobiaceae and individual classes of the Proteobacteria (see Supplementary Fig. S1, available with the online version of this paper) (Cavanaugh et al., 2001; Imhoff, 2001a, 2003; Kelly \& Wood, 2000; Kuever et al., 2002; Polz et al., 1996; Robertson \& Kuenen, 2001). In Apr lineage I, the Alphaproteobacteria formed a basal branching group separated into (1) the SAR11 clade, comprising Pelagibacter ubique (Giovannoni et al., 2005) and closely related environmental sequences, and (2) the SAR116 clade [environmental sequences derived from shotgun sequencing of Sargasso and Red Sea water samples (Venter et al., 2004; G. Sabehi and O. Beja, unpublished data)]. However, the close relatedness of Thiobacillus plumbophilus to the Alphaproteobacteria is discordant with its $16 \mathrm{~S}$ rRNA-genebased betaproteobacterial position. The second group of Apr lineage I consisted of the Gammaproteobacteria, with distinct clusters formed by (1) the symbiotic and related, free-living chemotrophic SOB (e.g. symbionts of Calyptogena magnifica and Bathymodiolus spp., strain OAII2) that are $16 \mathrm{~S}$ rRNA-discordantly in close affiliation with the group of betaproteobacterial Thiobacillus spp., and (2) the anoxygenic phototrophic Chromatiaceae. The Aprbased intrafamily branching order of the Chromatiaceae taxa was partially incongruent with the $16 \mathrm{~S}$ rRNA-genebased phylogeny (Imhoff, 2001a) and indicated putative LGT events among members of the Chromatiaceae (e.g. marine Thiococcus pfennigii strains were in closer affiliation with freshwater Allochromatium spp. than with saltrequiring Rhabdochromatium or halophilic Halochromatium spp.). In agreement with its 16S rRNA-gene-based

Table 4. Results of Southern blot assays with radioactively labelled aprA-specific probes and genomic DNA of SOB and SRB

\begin{tabular}{|c|c|c|c|c|c|}
\hline \multirow{2}{*}{$\begin{array}{l}\text { Genomic DNA of SOB species } \\
\text { (EcoRI/HindIII digestion) }\end{array}$} & \multirow[t]{2}{*}{ DSM $^{*}$} & \multicolumn{4}{|c|}{ Southern blot hybridization results with aprA-specific probe $\dagger$} \\
\hline & & $\begin{array}{l}\text { Chlorobium } \\
\text { limicola } 1855\end{array}$ & $\begin{array}{c}\text { Chlorobium } \\
\text { clathratiforme } 5477\end{array}$ & $\begin{array}{c}\text { Thiocapsa } \\
\text { roseopersicina } 4210^{\star *}\end{array}$ & $\begin{array}{c}\text { Desulfomicrobium } \\
\text { baculatum } 4028\end{array}$ \\
\hline \multicolumn{6}{|l|}{ Gammaproteobacteria } \\
\hline Thiocapsa roseopersicina & 217 & $+\ddagger$ & + & $++\ddagger$ & + \\
\hline Thiocapsa roseopersicina & $4210^{* *}$ & $+\ddagger$ & + & $++\ddagger$ & + \\
\hline \multicolumn{6}{|l|}{ Chlorobia } \\
\hline Chlorobium limicola & $245^{\star *}$ & - & - & - & - \\
\hline Chlorobium limicola & $248^{\star *}$ & - & - & - & - \\
\hline Chlorobium limicola & $1855^{\star *}$ & ++ & + & + & + \\
\hline Chlorobium luteolum & $262^{\star \star}$ & - & - & - & - \\
\hline Chlorobium luteolum & $273^{\star *}$ & - & - & - & - \\
\hline \multicolumn{6}{|l|}{ Deltaproteobacteria } \\
\hline Desulfomicrobium baculatum & 4028 & ++ & + & + & ++ \\
\hline
\end{tabular}

${ }^{\star}$ Cultures obtained from culture collection of J. Imhoff (laboratory internal numbers in italic type) are marked with ${ }^{\star *}$.

$\dagger$ Quality of hybridization results: -, no hybridization; +, hybridization signal; + +, strong hybridization signal.

¥Two hybridization signals obtained with genomic DNA of reference strain Thiocapsa roseopersicina DSM 217 and strain 4210 (culture collection of J. Imhoff). 
Table 5. Presence of sat, apr and qmo homologues coding for the dissimilatory ATP sulfurylase, the APS reductase and its putative functionally associated proteins (AprM and $\mathrm{OmoABC}$ ) in genome sequences of SOB (the genomic arrangement of the genes is indicated by the GenBank accession numbers of the encoded proteins)

Environm. seq., environmental sequence.

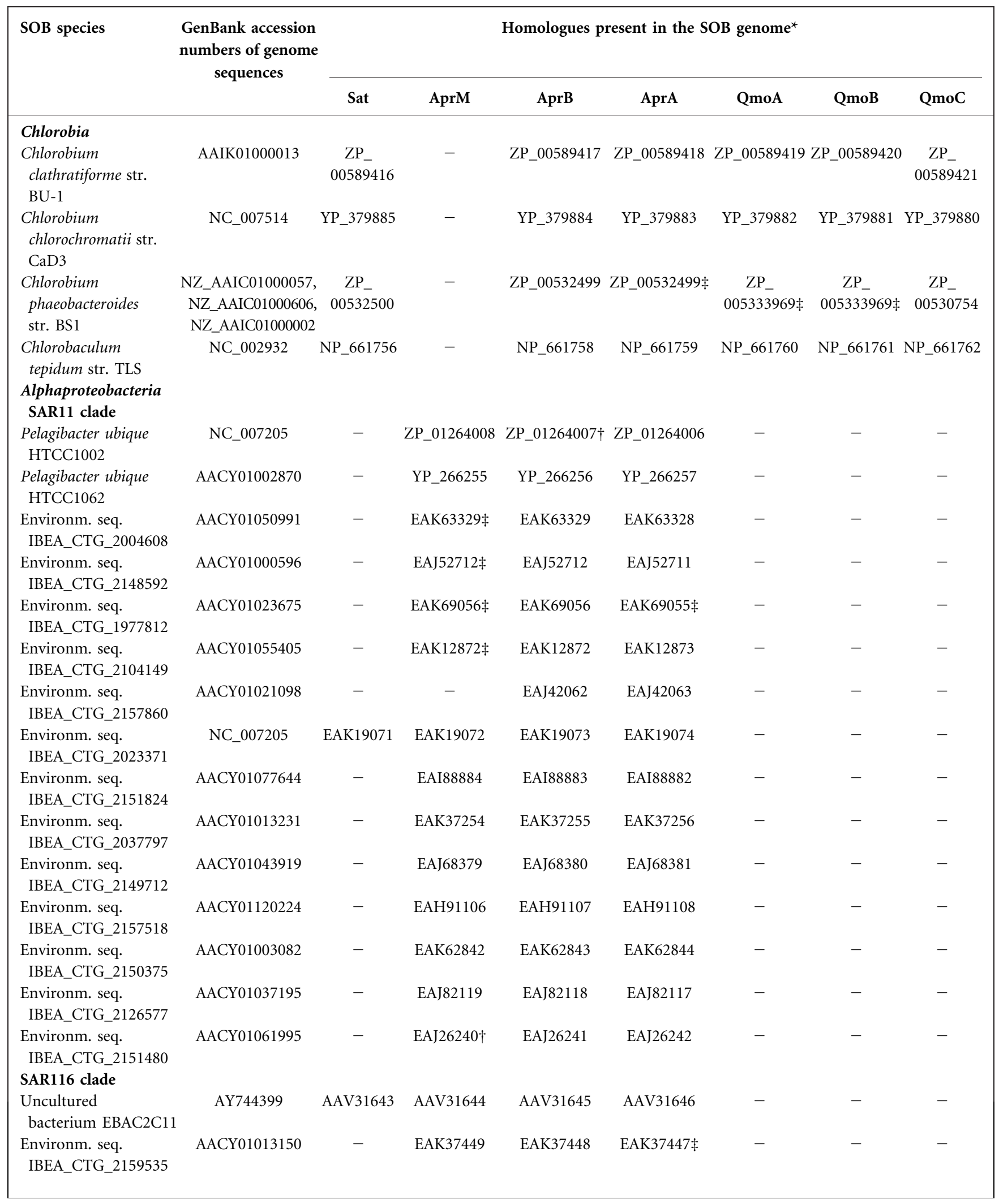


Table 5. cont.

\begin{tabular}{|c|c|c|c|c|c|c|c|c|}
\hline \multirow[t]{2}{*}{ SOB species } & \multirow{2}{*}{$\begin{array}{c}\text { GenBank accession } \\
\text { numbers of genome } \\
\text { sequences }\end{array}$} & \multicolumn{7}{|c|}{ Homologues present in the SOB genome ${ }^{\star}$} \\
\hline & & Sat & AprM & AprB & AprA & QmoA & QmoB & QmoC \\
\hline \multicolumn{9}{|l|}{ Betaproteobacteria } \\
\hline $\begin{array}{l}\text { Thiobacillus } \\
\text { denitrificans } \\
\text { ATCC } 25259\end{array}$ & NC_007404 & YP_314632 & YP_316042 & $\begin{array}{l}\text { YP_314631/ } \\
\text { YP_316041 }\end{array}$ & $\begin{array}{l}\mathrm{YP} \_314630 / \\
\mathrm{YP} \_316040\end{array}$ & YP_315406 & YP_315405 & - \\
\hline \multicolumn{9}{|l|}{ Gammaproteobacteria } \\
\hline $\begin{array}{l}\text { Allochromatium } \\
\text { vinosum }\end{array}$ & U84759\$ & AAC23622 & AAK16200 & AAC23620 & AAC23621 & - & - & - \\
\hline $\begin{array}{l}\text { Olavius algarvensis } \\
\text { Gamma-3 symbiont }\end{array}$ & AASZ_01000200 & + & + & + & + & - & - & - \\
\hline $\begin{array}{l}\text { Olavius algarvensis } \\
\text { Gamma-1 symbiont }\end{array}$ & $\begin{array}{l}\text { AASZ_01004101, } \\
\text { AASZ_01004100, } \\
\text { AASZ_01000461 }\end{array}$ & ND & - & $+\ddagger$ & $+\ddagger$ & + & + & - \\
\hline Endoriftia persephone & $\begin{array}{l}\text { AASF_01001200, } \\
\text { AASF_01001506, } \\
\text { AASF_01002103, } \\
\text { AASF_01001775, } \\
\text { AASF_01001739 }\end{array}$ & $+\ddagger$ & - & + & + & $+末$ & $+\ddagger$ & - \\
\hline $\begin{array}{l}\text { Cdt. Ruthia magnifica } \\
\text { str. CM }\end{array}$ & NC_008610 & YP_903355 & YP_903356 & YP_903357 & YP_903358 & & & \\
\hline
\end{tabular}

*The presence of protein encoding sat, aprBA, aprM and qmoABC homologues in the SOB genome is indicated by the GenBank accession number of the respective protein (or by + for the metagenomic sequences of the gammaproteobacterial symbiont of Olavius algarvensis).

$\dagger$ Incorrect gene annotation by automated protein coding gene prediction program in genome sequence.

$¥$ Incomplete gene sequences obtained from unfinished genome/environmental metagenome sequencing projects.

$\S$ Partial genome sequence obtained by cloning experiments.

phylogenetic assignment as a member of the genus Allochromatium, the AprBA-based trees confirmed the incorrect classification of SOB strain DSM 214 as a Thiocystis violacea subspecies.

The $d s r A B$-discordant branching position of Apr lineage II in the Apr trees points to putative lateral transfer of $a p r$ genes among SRP and SOB. This lineage comprised the proteins of the green sulfur bacteria and several members of the Chromatiaceae, Thiobacillus and invertebrate symbionts. While some of these beta- and gammaproteobacterial SOB harbour a second apr gene locus that codes for the putative resident, 'authentic' homologue (Apr lineage I), the majority exclusively possess aprBA genes of the SRPrelated Apr lineage II. In this lineage, the green sulfur bacteria formed a monophyletic group (sequence identity $>80.9 \%$ ) in closer affiliation with the reductive-operating Apr of the Thermodesulfovibrio-Desulfobacca cluster than with the other oxidative-acting APS reductases of the proteobacterial SOB. The latter group diverged in agreement with the 16S rRNA phylogeny into (1) the chemotrophic betaproteobacterial SOB (Thiobacillus), and (2) the chemo- and phototrophic gammaproteobacterial SOB (Thiothrix, symbionts from Riftia, Inanidrilus and Ifremeria and seven Chromatiaceae species). However, the AprBA-based basal branching of the phototrophic $\mathrm{Fe}(\mathrm{II})$-oxidizing Thiodictyon sp. strain F4 in closest affiliation with the Thiobacillus spp. was not consistent with its 16S rRNA-gene-based classification (Ehrenreich \& Widdel, 1994).

\section{Additional evidence for LGT of aprBA}

The presence of indels at identical positions in the AprBA alignments provides additional evidence for LGT events. In addition, the sequences were checked for recent LGT events by identification of atypical sequence characteristics (Lawrence \& Ochman, 1997), e.g. significant deviations in mol\% $\mathrm{G}+\mathrm{C}$ content and codon usage between the LGTderived gene and respective $\mathrm{SOB}$ genome, as well as the corresponding $d s r A B$ genes.

The separate phylogenetic position of Apr lineage I was confirmed by the presence of nine unique indels in the sequences of both subunits (see grey-shaded boxes in AprBA alignment, Supplementary Fig. S2 available with the online version of this paper). The separation into the alphaproteobacterial and the beta/gammaproteobacterial SOB group in the Apr lineage I was stressed by single, group-specific indels, whereas the $16 \mathrm{~S}$ rRNA-discordant 


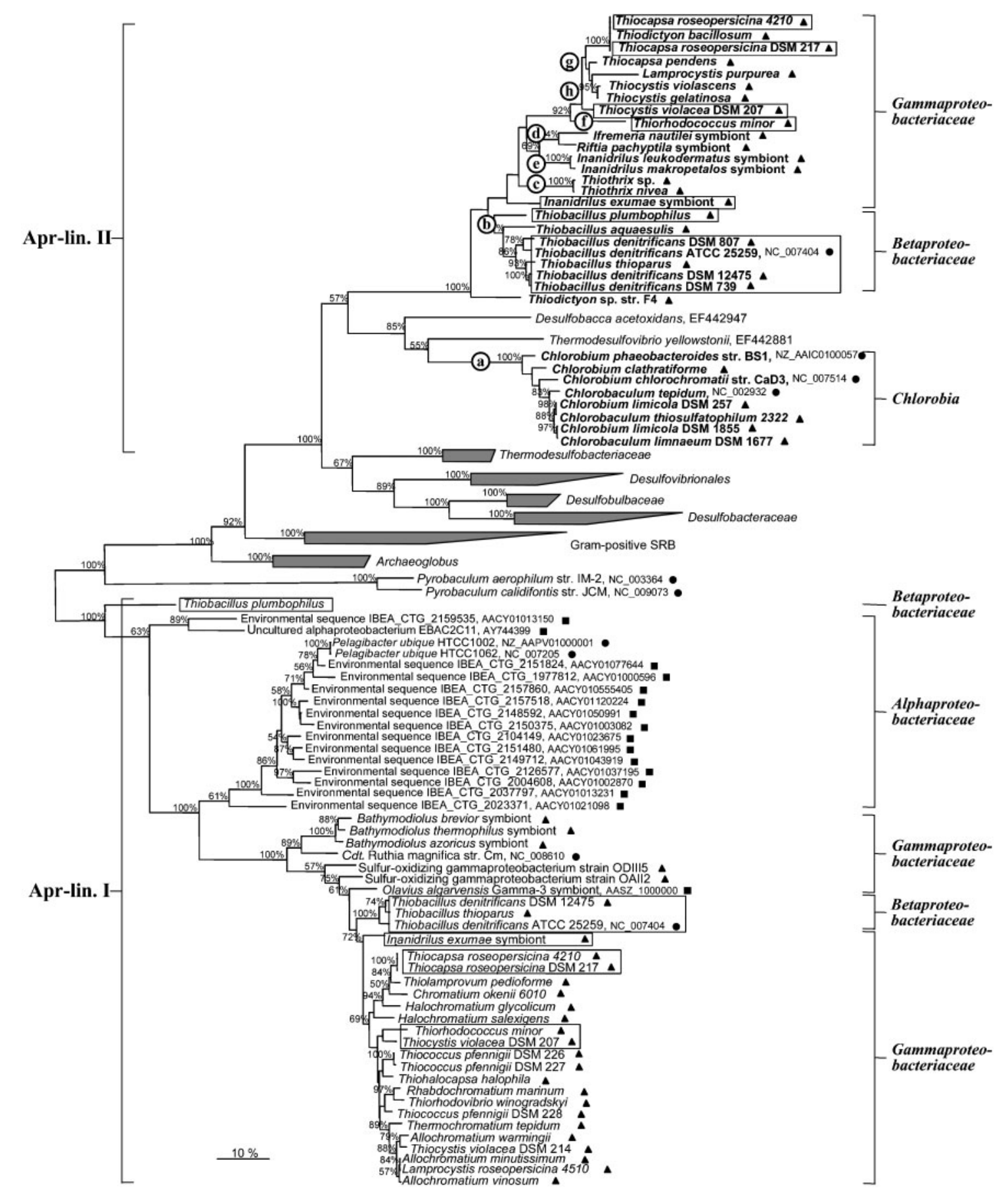

Fig. 1. Phylogenetic tree based on comparative analysis of 379 amino acid positions of 104 AprBA sequences from investigated SOB, including full-length AprBA sequences retrieved from public databases of SOB (genomic, metagenomic and PCR analysis-derived sequences are indicated by $\boldsymbol{\bullet}, \mathbf{\square}$ and $\boldsymbol{\Lambda}$, respectively) and selected SRP. The tree was inferred using the maximum-likelihood method. The DsrAB-congruent, presumably 'authentic' AprBA lineage I (Apr-lin. I) was used as the outgroup reference. SOB with DsrAB-discordant, putative laterally transferred aprBA genes are in bold type (Apr lineage II; Aprlin. II), while the reference strains with two apr copies are indicated with boxes. Proposed LGT events are indicated by letters $(a-h)$. The taxonomic classifications of investigated SOB based on the 16S rRNA gene phylogeny are indicated. The scale bar corresponds to $10 \%$ estimated sequence divergence. Cdt., Candidatus; str., strain. 


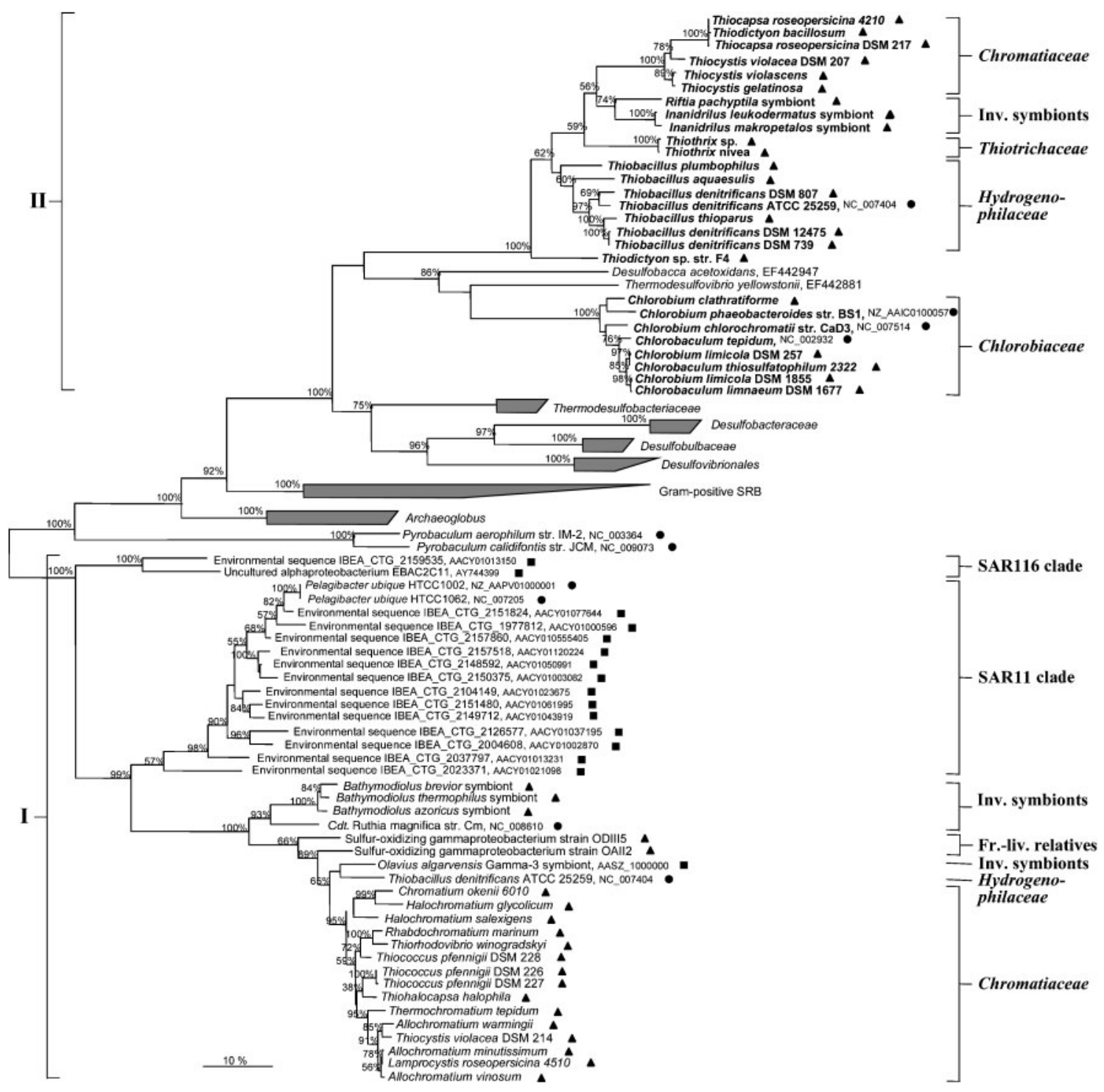

Fig. 2. Phylogenetic tree based on comparative analysis of 701 amino acid positions of 89 AprBA sequences from investigated SOB, including full-length AprBA sequences retrieved from public databases of SOB (genomic, metagenomic and PCR analysis-derived sequences are indicated by $\boldsymbol{\bullet}, \mathbf{\square}$ and $\boldsymbol{\Lambda}$, respectively) and selected SRP. The tree was inferred using the maximum-likelihood method. The DsrAB-congruent, presumably 'authentic' AprBA lineage I was used as the outgroup reference. SOB with DsrAB-discordant, putative laterally transferred aprBA genes are in bold type (Apr lineage II). The taxonomic classifications of investigated SOB based on the 16S rRNA gene phylogeny are indicated. The scale bar corresponds to $10 \%$ estimated sequence divergence. Cdt., Candidatus; str., strain; Inv., invertebrate; Fr.-liv., free-living.

branching positions of Thiobacillus plumbophilus and symbionts of Bathymodiolus spp. in the AprBA trees were supported by group-intermixed indels and further unique insertions in each subunit sequence. The affiliation of Chlorobiaceae and Thermodesulfovibrio AprBA proteins was confirmed by the presence of four shared indels, while their phylogenetic separation from the proteobacterial Apr sequences in Apr lineage II was proven by the existence of five unique indels. In addition, the $16 \mathrm{~S}$ rRNA-discordant closest affiliation of the Thiodictyon sp. strain F4 with the investigated chemotrophic SOB of the Beta- and Gammaproteobacteria was supported by three shared indels. The compositional similarity of the LGT-derived aprBA sequences of Apr lineage II to the respective recipient genomes points to an ancient timing of all inferred LGTs that affected the investigated SOB. This is also stressed by the strong congruence of the $\mathrm{mol} \% \mathrm{G}+\mathrm{C}$ content and codon usage of the corresponding aprBA sequences of those SOB that contain two apr gene loci, despite their distant relationship. 


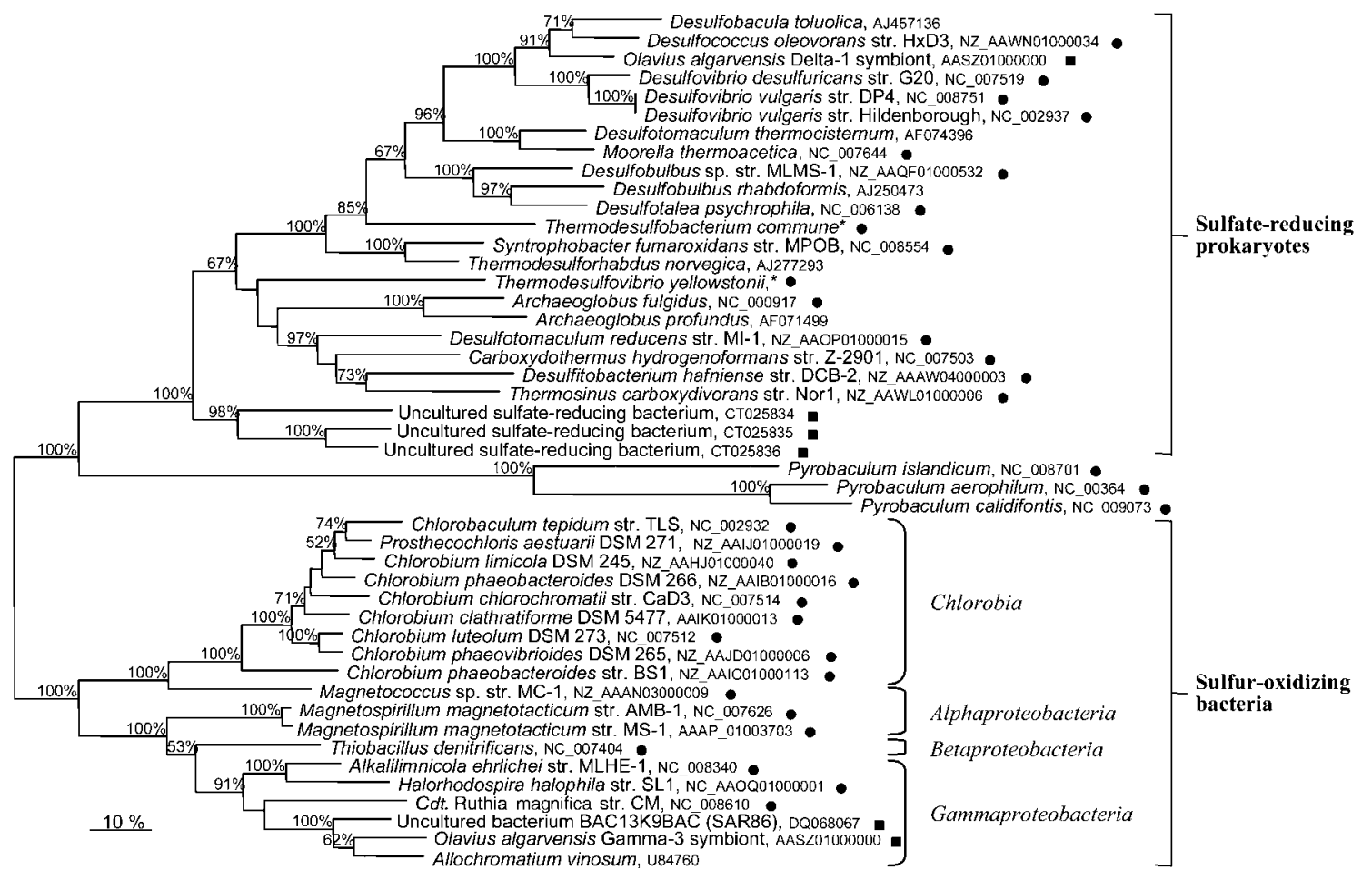

Fig. 3. Phylogenetic tree based on comparative analysis of 740 amino acid positions of 46 DsrAB sequences from full-length sequences retrieved from public databases of SOB and SRP (genomic and metagenomic sequences are indicated by $\bullet$ $\mathbf{\square}$, respectively). The tree was inferred using the maximum-likelihood method. The DsrAB lineage of SOB was used as the outgroup reference. The taxonomic classifications of SOB based on the 16S rRNA gene phylogeny are indicated. The scale bar corresponds to $10 \%$ estimated sequence divergence. Cdt., Candidatus; str., strain.

\section{Genomic arrangement of aprBA and functionally associated genes in SOB}

Interestingly, the phylogenetic divergence of the oxidativeoperating APS reductases into two distantly related lineages is reflected in the deviating presence and arrangement of sat, aprM, qmoABC and heterodisulfide reductase-encoding $(h d r)$ genes and other hypothetical proteins (UPF0153 and COG1576) in the SOB genomes (see Fig. 4, Table 5). The presumably LGT-unaffected, 'authentic' aprBA gene loci (Apr lineage I) of the photo- and chemotrophic Proteobacteria are always preceded by and co-transcribed with an aprM homologue which is not found in the genomes of SRP, Chlorobiaceae, Endoriftia persephone or Olavius algarvensis Gamma-1 symbiont, or adjacent to the LGT-affected apr gene locus II from Thiobacillus denitrificans. The native electron acceptor and transfer mechanism to the electron transport chain is unknown for the APS reductases of Apr lineage I. However, comparative sequence analysis predicts the protein AprM to contain five transmembrane helices with no sequence similarity to any currently known conserved domain or cofactor binding site in the databases. An essential structural function of AprM as a membrane anchor that allows the spatial and functional association of this type of oxidative APS reductase with the membrane has been postulated (Meyer \& Kuever, 2007).

In accordance with their affiliated AprBA proteins, the sataprBA-qmoABC genomic arrangement of the Chlorobiaceae is nearly identical to the gene organization of Thermodesulfovibrio yellowstonii (Fig. 4). The additional ORF located downstream of the sat gene in the genomes of thermophilic SRP is missing in the Chlorobiaceae; however, unusually long intergenic distances separate the sat and aprB genes in the latter, indicating the potential loss of this ORF after the transfer event. Interestingly, the gene composition and arrangement of the presumably LGTderived apr gene loci from Olavius algarvensis Gamma-1 symbiont, Endoriftia persephone and Thiobacillus denitrificans are more similar to the SRP than to the Chlorobiaceae. The qmo operons are truncated to a qmoAB gene locus (compare to Desulfotomaculum reducens and Syntrophobacter fumaroxidans, Fig. 4), but are located in a genomic position distant to that of the sat-aprBA operon. A separately transcribed $q m o C$ homologue could not be identified; however, $h d r C$ and $h d r B$ homologues (coding for functional subunits of the heterodisulfide reductase) are present near the qmoAB of Thiobacillus denitrificans, Olavius algarvensis Gamma-1 symbiont and Endoriftia 
$\underline{\mathrm{SOB}}$

$\begin{array}{ll}\text { Alphaproteobacteria } & \text { Pelagibacter ubique (SAR11) } \\ & \text { Env. Seq. IBEA_CTG_2023371 } \\ & \text { Uncult. Alphapr. EBAC2C11 (SAR116) } \\ & \text { Env. Seq. IBE__CTG_2159535 }\end{array}$

Gammaproteobacteria Allochromatium vinosum

Cdt. Ruthia magnifica symbiont

Olavius algarvensis Gamma-3 symbiont

Olavius algarvensis Gamma-1 symbiont

Endoriftia persephone

Betaproteobacteria Thiobacillus denitrificans

Chlorobiaceae

Chlorobaculum tepidum

Chlorobium clathratiforme

$\underline{\text { SRB }}$

Thermodesulfovibrio yellowstonii

Thermodesulfobacterium commune

Desulfotomaculum reducens

Syntrophobacter fumaroxidans

Uncult. SRB fosws 3917
'Authentic' apr gene loci of SOB (Apr lineage I) $\quad$ LGT-derived (SRP-related) apr gene loci of SOB (Apr lineage II)

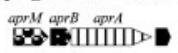

sat apos aprB apps

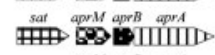

aprM appi aprd ?

sat apro apri apprA

sat 1 aprM appB apprA

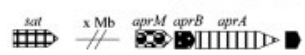

apr $\operatorname{apr} B$ aprA

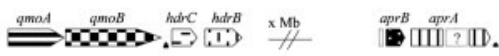

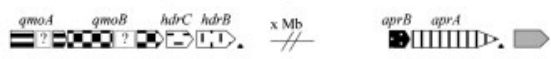

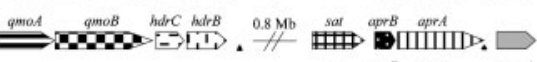

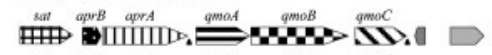
rat 衤 satm

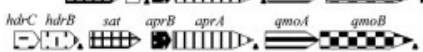

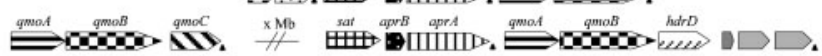
$\stackrel{\text { amas }}{=} \operatorname{amos} B$

- Hypoth. Prot. (COG 1576) $\square \underset{\text { SRB }}{\text { Hypoth. Prot. from thermophilic }}$

Hypoth. Prot.

Hypoth. Prot. (UPF0153 family)

- rho-independent transcription termination $\quad$ /t Non-scaled intergenetic space $\quad 2$ Unsequenced gene region

Fig. 4. Diagrammatic comparison of the genomic organization of the sat, apr and qmo genes in selected SOB and SRP (operon structure prediction by Softberry) in support of the inferred LGTs of the entire gene locus from SRP to certain SOB lineages. ORFs were designated based on BLASTX search results with significant homology scores. Loci: sat, dissimilatory ATP sulfurylase; apr $A$ and $a p r B, \alpha$ and $\beta$ subunits of the dissimilatory APS reductase; aprM, putative transmembrane protein; qmo $A, q m o B$ and $q m o C$, subunits of the putative APS : menaquinone oxidoreductase; $h d r B, h d r C$ and $h d r D$, subunits of heterodisulfide reductase. Abbreviations: Cdt., Candidatus; Env. Seq. environmental sequence; Uncult. Alphapr., uncultured alphaproteobacterium; Hypoth. Prot., hypothetical protein. 
persephone (see also Desulfotomaculum reducens and Syntrophobacter fumaroxidans, Fig. 4). Interestingly, the $q m o A B, h d r C$ and $h d r B$ genes of Thiobacillus denitrificans and Endoriftia persephone have been predicted to be cotranscribed. This might indicate that the electron transfer from cytoplasmic sulfite oxidation to the membrane quinone pool might be mediated by an SRP-like linking mechanism (Pires et al., 2003) in the Apr lineage II protein-containing SOB.

\section{DISCUSSION}

\section{Distribution of apr genes among anoxygenic phototrophic SOB}

In Allochromatium vinosum, the oxidation of intermediately stored sulfur globules has been demonstrated to depend on the activity of the reverse-acting sulfite reductase and membrane-spanning DsrMKJOP complex (Dahl et al., 2005; Pott \& Dahl, 1998; Sander et al., 2006). In support of a general, essential role in the oxidative sulfur metabolism of the Chlorobiaceae, Chromatiaceae and Ectothiorhodospiraceae (1) the $d s r A B$ and $d s r M K J O P$ genes are present in all currently sequenced genomes from representatives of the previous SOB lineages (Dahl et al., 2005; Sabehi et al., 2005; Sander et al., 2006) (see also Supplementary Table S1 available with the online version of this paper), and (2) the existence of $d s r$ operons has been confirmed by Southern blot assays in several further members (Dahl et al., 1999). The subsequent oxidation of sulfite can be mediated by either the reverse-operating APS reductase (Apr) or SAOR (Brune, 1995; Brüser et al., 2000; Kappler \& Dahl, 2001). Although the reverse-acting Apr has been demonstrated to be constitutively expressed, an essential in vivo role for this enzyme in the sulfur metabolism of Allochromatium vinosum has recently been questioned (Dahl, 1996; Sanchez et al., 2001). In support of the former results, the PCR-based analysis of this study indicated a generally restricted distribution of the dissimilatory APS reductase-encoding genes among the investigated anoxygenic phototrophic SOB (Table 1). While the presence of apr genes could be proven for most Chromatiaceae spp. (except marine Isochromatium and Marichromatium), they are absent in the investigated Ectothiorhodospiraceae species and restricted in the Chlorobiaceae to members of subclusters 3 and $4 \mathrm{~b}$ (Imhoff, 2003). Generally, the results of our molecular analysis are in agreement with those of earlier enzyme activity studies (Brune, 1995; Dahl \& Trüper, 1994; Trüper \& Fischer, 1982); however, the reported APS reductase activity in cell extracts of Chlorobium limicola DSM 245, 'Chlorobium vibrioforme f. thiosulfatophilum' NCIB 8346 (Chlorobaculum parvum 2352 in Table 1) and Chlorobium phaeovibrioides DSM 270 (Brune, 1995; Dahl \& Trüper, 1994) are not supported. Because all available AprBA sequences of green sulfur bacteria are highly similar in sequence $(>80.9 \%$ sequence identity) and possess complementary primer target sites, amplification failure can be excluded. In addition, the proposed absence of apr genes of several Chlorobiaceae species of subcluster $2 \mathrm{~b}$ and $3 \mathrm{~b}$ was confirmed by Southern blot analysis using an aprA probe that encompassed the strictly conserved gene region coding for the APS/ sulfite binding site (see hybridization results with Desulfomicrobium baculatum, Table 4). Therefore, the existence of apr genes that encode functional enzymes could be excluded for the investigated reference strains. Further evidence for the correctness of our PCR results is given by the consistent negative BLAST search results for the currently sequenced genomes of $C$. limicola DSM 245, Chlorobium luteolum DSM 273 and Chlorobium ferrooxidans.

Growth experiments with aprBA-deficient strains of Allochromatium vinosum showed that the loss of reverse APS reductase activity had no effect on the specific growth rate and sulfite-oxidizing ability. The sulfite oxidation has been calculated to rely to $69-100 \%$ on the activity of the coexisting SAOR under photolithoautotrophic conditions (Sanchez et al., 2001). Because all green and purple sulfur bacteria investigated in this study are capable of complete sulfide/sulfur oxidation to sulfate, the observed lack of $a p r$ genes in most examined species might be indirect evidence for the presence and functional importance of the AMPindependent pathway in the oxidative sulfur metabolism of SOB. Indeed, the existence of an SAOR has been established by enzyme assays for several representatives that do not possess the APS pathway, e.g. Marichromatium spp. (Trüper \& Fischer, 1982). The SAOR of Allochromatium vinosum has been suggested to be a molybdenumcontaining protein (Dahl, 1996), like the well-documented enzyme of Starkeya novella, SorAB (Kappler \& Dahl, 2001; Kappler \& Bailey, 2005). With regard to its functional association with the essential reverse sulfite reductase (Pott \& Dahl, 1998), a cytoplasmically localized SAOR is postulated for the anoxygenic phototrophic SOB. Indeed, periplasmic SorAB-encoding homologues could not be identified in the currently sequenced genomes of Chlorobiaceae and Ectothiorhodospiraceae. The presence of an additional sulfite-oxidation pathway via APS-reductase (and ATP sulfurylase) besides the SAOR would allow molybdenum-independent sulfite oxidation and might be a selective advantage under certain photolithotrophic conditions (e.g. allowing a greater supply of reducing equivalents at saturating irradiances), or during chemolithoautotrophic growth (observed for several Chromatiaceae; Imhoff, 2001a).

In accordance with earlier results based on enzyme assays (Brune, 1995; Friedrich, 1998; Trüper \& Fischer, 1982), apr genes were not detected in the investigated phototrophic Alphaproteobacteria (Table 1). Indeed, their representatives have been reported to prefer a photoorganoheterotrophic mode of growth and to vary considerably in their ability to use reduced sulfur compounds as photosynthetic electron donors (Brune, 1995; Imhoff, 2001b). If utilized, sulfide is primarily converted (by SQR) to elemental sulfur instead 
of sulfate (Griesbeck et al., 2000). The absence of apr and $d s r$ genes in their genomes confirms their use of a different enzymic sulfur oxidation system compared to the cytoplasmic pathway of the previously discussed SOB lineages. Interestingly, the only members of the Alphaproteobacteria that harbour apr genes in their genomes (Table 5) are Pelagibacter ubique subsp. (SAR11) and an uncultured putative SOB of the SAR116 clade. Since they lack sat and $d s r A B$ genes, a dissimilatory function of the APS reductase in their sulfur metabolism can be excluded. The reverseacting APS reductase might primarily be used for detoxification of sulfite to prevent its cytoplasmic accumulation during the degradation of organic sulfur compounds. Indeed, members of the SAR11 clade have been demonstrated to dominate the assimilation of dissolved dimethylsulfoniopropionate (DMSP) in the surface ocean (Malmstrom et al., 2004).

\section{Distribution of apr genes among chemotrophic SOB}

Diverse enzymic systems have been suggested to be involved in the aerobic oxidation of sulfide/sulfur to sulfate in the phylogenetically divergent chemotrophic $\mathrm{SOB}$, comprising primarily the periplasmic enzymes SQR, sulfur dioxygenase (SDR) and SAOR (Brüser et al., 2000; Friedrich, 1998; Griesbeck et al., 2000; Kappler \& Dahl, 2001; Kelly, 1999; Rohwerder \& Sand, 2003; Suzuki, 1994; Takai et al., 2005; Teske \& Nelson, 2004; Theissen et al., 2003). Consistently, this study revealed the apr genes to be restricted among the chemotrophic SOB to representatives of Thiobacillus, Thiothrix and invertebrate symbionts, including some of their free-living relatives, in accordance with earlier enzyme activity studies (Friedrich, 1998; Nelson \& Fisher, 1995; Odintsova et al., 1993; Taylor, 1994). Furthermore, APS reductase activity has been found in obligate chemolithoautotrophic, marine Beggiatoa subspecies but seems to be absent in mixo- or even heterotrophic freshwater strains (Teske \& Nelson, 2004) as confirmed by this molecular analysis. In congruence to the results of this study (Table 1), no APS reductase has been reported to be involved in the oxidative sulfur metabolism of Thiomicrospira spp. (Nelson \& Fisher, 1995), Sulfurimonas denitrificans (Takai et al., 2005) and acidophilic SOB (Brüser et al., 2000). The sulfur metabolism of Aquaspirillum, Macromonas and Spirochaeta spp. (Dubinina et al., 2004; LaRiviere \& Schmidt, 2001) has not yet been investigated by enzyme studies.

Interestingly, most chemotrophic SOB that possess apr genes are facultative anaerobes with the ability to switch between aerobic and anaerobic modes of growth (Brüser et al., 2000; Cavanaugh et al., 2001; Kuever et al., 2002; Nelson \& Fisher, 1995; Robertson \& Kuenen, 2001). The cytoplasmic enzyme system (Dsr, Apr and Sat/APAT) might operate in these chemotrophic SOB in a manner analogous to that of the anoxygenic phototropic Chromatiaceae (and Chlorobiaceae), with significant energetic advantages for chemothioautotrophic growth under oxygen limitation (electron transport phosphorylation-coupled sulfur oxidation; electrons enter the electron transport chain at the energetic level of quinones with a higher number of coupling sites available to drive ATP synthesis and lower energy demand for reverse electron flow; substrate phosphorylation-coupled sulfite oxidation). Indeed, the expression and involvement of Dsr, Apr and Sat in the sulfur oxidation process has been confirmed for anaerobically grown cultures of Thiobacillus denitrificans (Beller et al., 2006; Schedel \& Trüper, 1980) and the endosymbiont of Riftia pachyptila (Markert et al., 2007). A general involvement of the latter pathway was suggested by Kelly (1999), based on the greater molar growth yields of Thiobacillus denitrificans compared to Sulfurimonas denitrificans even under aerobic conditions. In contrast, the involvement of an extracytoplasmic sulfur-oxidation pathway (via SQR, SDR and SAOR) might in principle be more advantageous (no requirement for energy-demanding sulfur compound permease systems; no cytoplasmic accumulation of toxic substrates or products; no acidification of the cytoplasm while the extracytoplasmic localization of substrate oxidation contributes to the proton gradient).

The enzymes of the archaeal sulfur-oxidation pathway (e.g. the unique sulfur oxygenase reductase) represent convergent evolutionary lines compared to the bacterial proteins (Brüser et al., 2000; Kletzin et al., 2004). Based on enzyme activity assays, an involvement of the reverse APS reductase in the sulfite oxidation of Acidianus ambivalens has been postulated, despite high levels of non-enzymic background (Zimmermann et al., 1999). In contrast, the results of our molecular study do not support its involvement in the oxidative sulfur metabolism of Sulfolobales representatives, including Acidianus ambivalens.

\section{Phylogeny of dissimilatory APS reductase from SOB indicates lateral transfer of aprBA genes between SRP and SOB}

The DsrAB phylogeny presents the oxidative-operating sulfite reductases of $\mathrm{SOB}$ as monophyletic and distantly related to the reductive enzyme type of the SRP (Fig. 3). In contrast, the reverse APS reductases of photo- and chemotrophic SOB appear to have diverged into two distinct phylogenetic clusters, comprising the DsrABcongruent Apr lineage I and the DsrAB-discordant Apr lineage II (Figs 1 and 2). Accumulating experimental evidence confirms the postulated essential function of the reverse sulfite reductase (including the DsrMKJOP transmembrane redox complex) in the dissimilatory sulfur metabolism of SOB (Beller et al., 2006; Dahl et al., 1999, 2005; Pott \& Dahl, 1998; Sander et al., 2006) (also reflected by the ubiquitous presence of $d s r$ homologues in genomes; Supplementary Table S1). Thus, the DsrAB-congruent phylogenetic placement most likely represents the 'authentic', LGT-unaffected position of SOB in the Apr tree. The most reasonable explanation for the presence of the 
SRP-related apr genes (Apr lineage II) in Chlorobiaceae and several Beta- and Gammaproteobacteria (in some representatives in addition to the 'authentic' apr gene locus) is the occurrence of multiple LGT events between SRP and SOB. In analogy, the SRP-affiliated $d s r M K J O P$ genes of green sulfur bacteria have recently been postulated to have been acquired via lateral transfer from an unknown SRP donor (Sander et al., 2006). Because the AprBA proteins of Chlorobiaceae are more closely related to the Thermodesulfovibrio-Desulfobacca cluster than to the Beta- and Gammaproteobacteria (Figs 1 and 2), these SOB groups will have received their LGT-derived apr genes independently. Although direct SRP donor lineages are not apparent, putative thermophilic strains might have transferred their apr genes concurrently to ancestral strains of the aforementioned groups. A direct lateral transfer of the entire gene locus from the Thermodesulfovibrio donor lineage to the Chlorobiaceae is supported by (1) the similarity of their indel pattern (Supplementary Fig. S2 available with the online version of this paper), (2) the congruent arrangement of the sat, apr and qmoABC genes in the genomes (Fig. 4), as well as (3) the Apr-consistent topologies of the Sat and QmoABC phylogenetic trees (not shown). The restricted distribution of the apr genes among the green sulfur bacteria might indicate that the LGT occurred after their diversification into marine and freshwater strains (Imhoff, 2003). The LGT-derived character of proteobacterial proteins of Apr lineage II is supported by the fact that the SRP-affiliated proteins are restricted to a few beta- and gammaproteobacterial genera and mainly comprise species that harbour two aprBA gene loci of which one codes for a presumably 'authentic' protein (Tables 1 and 3). Additional support for an SRP origin of the Apr lineage II proteins in Proteobacteria is given by (1) the similar gene locus composition and organization in the betaproteobacterial Thiobacillus denitrificans and Olavius algarvensis Gamma-1 symbiont compared to the SRP (Table 5 and Fig. 4), and (2) their close relationship on the basis of the $\mathrm{QmoA} / \mathrm{B}$ proteins (tree not shown). The apr genes might have been received via at least seven independent LGT events by the ancestors of Thiobacillus, Thiothrix, the invertebrate Gamma-1 and -4 symbionts, the Thiocapsa-Thiodictyon-Lamprocystis cluster, Thiocystis and Thiorhodococcus. After diversification, the resident, 'authentic' apr gene might have been replaced in several species by its SRP-affiliated xenologue (xenologous gene displacement), causing the observed polyphyly of the Beta- and Gammaproteobacteria in the Apr-based tree. Indeed, close associations and synergistic interactions between those SOB species that harbour SRPrelated aprBA genes and SRP have been reported from various habitats and even in invertebrate tissues (Bright \& Giere, 2005; Imhoff, 2001a; Markert et al., 2007; Overmann \& Garcia-Pichel, 2001; Tonolla et al., 2004; Visscher et al., 1992). Microbial biofilms and mats have been demonstrated to be especially hot spots for LGT involving different physiological groups of prokaryotes (Molin \& Tolker-Nielsen, 2003; Sorensen et al., 2005).
Notably, some inferred relationships in the Apr lineage I subtree are discordant with the $16 \mathrm{~S}$ rRNA-gene-based species phylogeny and indicate the occurrence of putative lateral transfers even among the SOB, e.g. the SAR116affiliated AprBA proteins of Thiobacillus plumbophilus. Furthermore, the correlation of the salt requirementcorrelated Chromatiaceae classification is not reflected in the Apr-based tree (Imhoff, 2001a). Interestingly, the Aprbased intrafamily branching order is confirmed by the sulfate thiohydrolase (SoxB)-based phylogeny (Meyer et al., 2007). In contrast to the $16 \mathrm{~S}$ rRNA-gene-based phylogeny (Cavanaugh et al., 2001), the AprBA proteins of Bathymodiolus spp. and Calyptogena magnifica symbionts form a basal-branching group in the Apr lineage I distinct from their closest relatives Olavius algarvensis Gamma-1 symbiont, and SOB strains OAII2 and ODIII5 (Kuever et al., 2002). This might be a result of their vertical mode of transmission (Cary \& Giovannoni, 1993; Hurtado et al., 2003), which disconnects the mussel- and bivalve-inhabiting $\mathrm{SOB}$ populations from their free-living counterparts and causes elevated evolutionary rates and genetic drift in the symbiotic population by co-adaptation to the host (Peek et al., 1998). The symbiotic bacteria of vestimentiferan tube worms and gastropods that are instead environmentally acquired by their hosts from free-living populations (Bright \& Giere, 2005; Cavanaugh et al., 2001; Nelson \& Fisher, 1995) have had a higher probability of interspecies gene exchange with the environmental microbial community and harbour xenologous apr genes (Fig. 1). A recent $16 \mathrm{~S}$ rRNA gene analysis of thiotrophic symbionts in Inanidrilus spp. (oligochaetes) has revealed the presence of Gamma-4 symbionts in Inandrilus exumae (Bergin et al., 2006), which replace the sulfur-oxidizing Gamma-1 symbionts found in other Inanidrilus spp. (Blazejak et al., 2006; Bright \& Giere, 2005). The distant relationship of the Inandrilus exumae Gamma-4 symbiont is reflected in the Apr-based tree and in the presence of two apr gene loci that encode proteins of both lineages.

\section{Putative functional importance of SRP-related APS reductases in SOB}

The postulated distinct electron-transfer strategies via AprM or Qmo/Hdr are supported by observed differences in the degrees of membrane binding of lineage I and II APS reductases in the photo- and chemotrophic SOB species (Brüser et al., 2000; Dahl \& Trüper, 1994; Friedrich, 1998). Interestingly, in Chromatiaceae species that contain apr genes which code for lineage I proteins (e.g. Allochromatium vinosum and Allochromatium warmingii), the APS reductases have been reported to be firmly membrane-bound, whereas they have been described as being soluble in those species that harbour the SRP-related apr genes encoding the lineage II proteins (e.g. Thiocapsa roseopersicina). A functionally important role for the LGTderived APS reductases in SOB is indicated by the preferential expression of the SRP-related apr gene locus compared to the concurrent 'authentic' one in cells of 
Thiocapsa roseopersicina (only the soluble APS reductase form is detected in culture; Dahl \& Trüper, 1994) and Thiobacillus denitrificans (transcriptional analysis; Beller et al., 2006). Recent proteome analysis of Endoriftia persephone has confirmed the essential role of the SRPrelated APS reductase in the sulfur-dependent energy metabolism of that micro-organism (Markert et al., 2007). Interestingly, Thiobacillus denitrificans, Olavius algarvensis Gamma-1 symbiont and Endoriftia persephone harbour SRP-related $q m o A B$ and $h d r C B$ homologues in their genomes, indicating the presence of an SRP-related mechanism linking cytoplasmic sulfite oxidation to the membrane quinone pool (Fig. 4). Indeed, qmoB has been demonstrated to be expressed in addition to aprBA in chemolithoautotrophically growing Endoriftia persephone (Markert et al., 2007). By analogy with the postulated interaction of DsrAB and transmembrane complex DsrMKJOP via conserved cysteine residues in DsrC proteins (Dahl et al., 2005; Pires et al., 2006), the SRPrelated reverse APS reductase and the QmoAB-HdrCB complex might couple the cytoplasmic sulfite/APS redox process to the electron transport chain by reversible disulfide/thiol interchanges. With regard to the multiple xenologous aprBA gene displacements, e.g. in chemotrophic Thiobacillus spp. and gammaproteobacterial SOB, the SRP-related APS reductase and electron transfer mechanism might be more advantageous for chemolithotrophic growth. Indeed, the members of the Chromatiaceae genera that contain SRP-related apr gene loci (Table 1) have been demonstrated to be physiologically versatile, e.g. by their ability to switch between photo- and chemolithoautotrophic lifestyles (Imhoff, 2001a). The two-gene state might be an intermediate in the replacement of the resident essential gene by the LGT-derived foreign homologue. However, the genomic persistence of both gene loci might allow the adaptation of the energy conservation process when growing (1) in dynamic and unstable habitats such as microbial mats with diurnal oscillating sulfide and oxygen concentrations, or (2) in competition with chemotrophic SOB (Imhoff, 2001a; Overmann \& Garcia-Pichel, 2001), and might be a selective advantage, especially for non-motile species such as Thiocapsa roseopersicina (Imhoff, 2001a).

\section{ACKNOWLEDGEMENTS}

This study was supported by grants of the BMBF (project 'Caribflux' under contract no. 03G0154C), the DFG (under contract no. KU 916/ 8-1) and the Max Planck Society, Munich.

\section{REFERENCES}

Beller, H. R., Chain, P. S. G., Letain, T. E., Chakicherla, A., Larimer, F. W., Richardson, P. M., Coleman, M. A., Wood, A. P. \& Kelly, D. P. (2006). The genome sequence of the obligately chemolithoautotrophic, facultatively anaerobic bacterium Thiobacillus denitrificans. J Bacteriol 188, 1473-1488.

Bergin, C., Berwig, N., Blazejak, A., Rühland, C. \& Dubilier, N. (2006). Novel Symbiont in the Gutless Marine Oligochaete Inanidrilus exumae. Poster no. P037 presented at the International Symposium on Microbial Sulfur Metabolism (ISMSM), Münster, 29 June to 2 July 2006.

Blazejak, A., Kuever, J., Erseus, C., Amann, R. \& Dubilier, N. (2006). Phylogeny of $16 \mathrm{~S}$ rRNA, ribulose 1,5-bisphosphate carboxylase/ oxygenase and adenosine 5 '-phosphosulfate reductase genes from gamma- and alphaproteobacterial symbionts in gutless marine worms (Oligochaeta) from Bermuda and the Bahamas. Appl Environ Microbiol 72, 5527-5536.

Bright, M. \& Giere, O. (2005). Microbial symbiosis in Annelida. Symbiosis 38, 1-45.

Brune, D. C. (1995). Sulfur compounds as photosynthetic electron donors. In Anoxygenic Photosynthetic Bacteria, pp. 847-870. Edited by R. E. Blankenship, M. T. Madigan \& C. E. Bauer. Dordrecht: Springer.

Brüser, T., Lens, P. N. L. \& Trüper, H. G. (2000). The biological sulfur cycle. In Environmental Technologies to Treat Sulfur Pollution, pp. 4786. Edited by P. N. L. Lens \& L. H. Pol. London: IWA Publishing.

Cary, S. C. \& Giovannoni, S. J. (1993). Transovarial inheritance of endosymbiotic bacteria in clams inhabiting deep-sea hydrothermal vents and cold seeps. Proc Natl Acad Sci U S A 90, 5695-5699.

Cavanaugh, C. M., McKiness, Z. P., Newton, I. L. G. \& Stewart, F. J. (2001). Marine chemosynthetic symbioses. In The Prokaryotes an Evolving Electronic Resource for the Microbial Community. Edited by M. Dworkin, E. Falkow, E. Rosenberg, K.-H. Schleifer \& E. Stackebrandt. New York: Fischer Verlag.

Dahl, C. (1996). Insertional gene inactivation in a phototrophic sulphur bacterium: APS-reductase-deficient mutants of Chromatium vinosum. Microbiology 142, 3363-3372.

Dahl, C. \& Trüper, H. G. (1994). Enzymes of dissimilatory sulfide oxidation in phototrophic sulfur bacteria. In Inorganic Microbial Sulfur Metabolism (Methods in Enzymology, vol. 243), pp. 400-421. Edited by H. Peck Jr., J. LeGall, J Abelson \& M. Simon. San Diego, CA: Academic Press.

Dahl, C., Rakhely, G., Pott-Sperling, A. S., Fodor, B., Takacs, M., Toth, A., Kraeling, M., Gyorfi, K., Kovacs, A. \& other authors (1999). Genes involved in hydrogen and sulfur metabolism in phototrophic sulfur bacteria. FEMS Microbiol Lett 180, 317-324.

Dahl, C., Engels, S., Pott-Sperling, A. S., Schulte, A., Sander, J., Lubbe, Y., Deuster, O. \& Brune, D. C. (2005). Novel genes of the $d s r$ gene cluster and evidence for close interaction of Dsr proteins during sulfur oxidation in the phototrophic sulfur bacterium Allochromatium vinosum. J Bacteriol 187, 1392-1404.

Dubinina, G. A., Grabovich, M. Y. \& Chernyshova, Y. Y. (2004). The role of oxygen in the regulation of the metabolism of aerotolerant Spirochetes, a major component of "Thiodendron" bacterial sulfur mats. Microbiologiia 73, 725-733 (in Russian).

Ehrenreich, A. \& Widdel, F. (1994). Anaerobic oxidation of ferrous iron by purple bacteria, a new type of phototrophic metabolism. Appl Environ Microbiol 60, 4517-4526.

Friedrich, C. G. (1997). Physiology and genetics of sulfur-oxidizing bacteria. In Advances in Microbial Physiology, 39, pp. 235-289. Edited by R. K. Poole. San Diego, CA: Academic Press.

Friedrich, M. W. (2002). Phylogenetic analysis reveals multiple lateral transfers of adenosine- $5^{\prime}$-phosphosulfate reductase genes among sulfate-reducing microorganisms. J Bacteriol 184, 278-289.

Friedrich, C. G., Rother, D., Bardischewsky, F., Quentmeier, A. \& Fischer, J. (2001). Oxidation of reduced inorganic sulfur compounds by bacteria: emergence of a common mechanism? Appl Environ Microbiol 67, 2873-2882.

Fritz, G., Buchert, T., Huber, H., Stetter, K. O. \& Kroneck, P. M. H. (2000). Adenylylsulfate reductases from archaea and bacteria are 1:1 $\alpha \beta$-heterodimeric iron-sulfur flavoenzymes - high similarity of 
molecular properties emphasizes their central role in sulfur metabolism. FEBS Lett 473, 63-66.

Fritz, G., Roth, A., Schiffer, A., Buchert, T., Bourenkov, G., Bartunik, H. D., Huber, H., Stetter, K. O., Kroneck, P. M. H. \& Ermler, U. (2002). Structure of adenylylsulfate reductase from the hyperthermophilic Archaeoglobus fulgidus at 1.6- $\AA$ resolution. Proc Natl Acad Sci U S A 99, 1836-1841.

Giovannoni, S. J., Tripp, H. J., Givan, S., Podar, M., Vergin, K. L., Baptista, D., Bibbs, L., Eads, J., Richardson, T. H. \& other authors (2005). Genome streamlining in a cosmopolitan oceanic bacterium. Science 309, 1242-1245.

Griesbeck, C., Hauska, G. \& Schütz, M. (2000). Biological sulfide oxidation: sulfide-quinone reductase (SQR), the primary reaction. In Recent Research Developments in Microbiology, 4, pp. 179-203. Edited by S. G. Pandalai. Trivadrum, India: Research Signpost.

Haveman, S. A., Greene, E. A., Stilwell, C. P., Voordouw, J. K. \& Voordouw, G. (2004). Physiological and gene expression analysis of inhibition of Desulfovibrio vulgaris Hildenborough by nitrite. J Bacteriol 186, 7944-7950.

Hipp, W. M., Pott, A. S., Thum-Schmitz, N., Faath, I., Dahl, C. \& Trüper, H. G. (1997). Towards the phylogeny of APS reductases and sirohaem sulfite reductases in sulfate-reducing and sulfur-oxidizing prokaryotes. Microbiology 143, 2891-2902.

Huber, H. \& Prangishvili, D. (2000). Sulfolobales. In The Prokaryotes an Evolving Electronic Resource for the Microbial Community. Edited by M. Dworkin, E. Falkow, E. Rosenberg, K.-H. Schleifer \& E. Stackebrandt. New York: Fischer Verlag.

Hurtado, L. A., Mateos, M., Lutz, R. A. \& Vrijenhoek, R. C. (2003). Coupling of bacterial endosymbiont and host mitochondrial genomes in the hydrothermal vent clam Calyptogena magnifica. Appl Environ Microbiol 69, 2058-2064.

Imhoff, J. F. (2001a). The Chromatiaceae. In The Prokaryotes an Evolving Electronic Resource for the Microbial Community. Edited by M. Dworkin, E. Falkow, E. Rosenberg, K.-H. Schleifer \& E. Stackebrandt. New York: Springer Verlag.

Imhoff, J. F. (2001b). The phototrophic alpha-Proteobacteria. In The Prokaryotes an Evolving Electronic Resource for the Microbial Community. Edited by M. Dworkin, E. Falkow, E. Rosenberg, K.-H. Schleifer \& E. Stackebrandt. New York: Springer Verlag.

Imhoff, J. F. (2003). Phylogenetic taxonomy of the family Chlorobiaceae on the basis of $16 \mathrm{~S}$ rRNA and fmo (Fenna-MatthewsOlson protein) gene sequences. Int J Syst Evol Microbiol 53, 941-951.

Kappler, U. \& Bailey, S. (2005). Molecular basis of intramolecular electron transfer in sulfite-oxidizing enzymes is revealed by high resolution structure of a heterodimeric complex of the catalytic molybdopterin subunit and a $c$-type cytochrome subunit. J Biol Chem 280, 24999-25007.

Kappler, U. \& Dahl, C. (2001). Enzymology and molecular biology of prokaryotic sulfite oxidation. FEMS Microbiol Lett 203, 1-9.

Kelly, D. P. (1999). Thermodynamic aspects of energy conservation by chemolithotrophic sulfur bacteria in relation to the sulfur oxidation pathways. Arch Microbiol 171, 219-229.

Kelly, D. P. \& Wood, A. P. (2000). Reclassification of some species of Thiobacillus to the newly designated genera Acidithiobacillus gen. nov., Halothiobacillus gen. nov. and Thermithiobacillus gen. nov. Int J Syst Evol Microbiol 50, 511-516.

Klein, M., Friedrich, M., Roger, A. J., Hugenholtz, P., Fishbain, S., Abicht, H., Blackall, L. L., Stahl, D. A. \& Wagner, M. (2001). Multiple lateral transfers of dissimilatory sulfite reductase genes between major lineages of sulfate-reducing prokaryotes. J Bacteriol 183, 6028-6035.
Kletzin, A., Urich, T., Muller, F., Bandeiras, T. M. \& Gomes, C. M. (2004). Dissimilatory oxidation and reduction of elemental sulfur in thermophilic archaea. J Bioenerg Biomembr 36, 77-91.

Kuever, J., Sievert, S. M., Stevens, H., Brinkhoff, T. \& Muyzer, G. (2002). Microorganisms of the oxidative and reductive part of the sulfur cycle at a shallow-water hydrothermal vent in the Aegean Sea (Milos, Greece). Cah Biol Mar 43, 413-416.

Kwok, S., Kellogg, D. E., McKinney, N., Spasic, D., Goda, L., Levenson, C. \& Sninsky, J. J. (1990). Effects of primer-template mismatches on the polymerase chain reaction. Nucleic Acids Res 18, 999-1005.

LaRiviere, J. W. M. \& Schmidt, K. (2001). Morphologically conspicuous sulfur-oxidizing Eubacteria. In The Prokaryotes an Evolving Electronic Resource for the Microbial Community. Edited by M. Dworkin, E. Falkow, E. Rosenberg, K.-H. Schleifer \& E. Stackebrandt. New York: Fischer Verlag.

Lawrence, J. G. \& Ochman, H. (1997). Amelioration of bacterial genomes: rates of change and exchange. J Mol Evol 44, 383-397.

Malmstrom, R. R., Kiene, R. P., Cottrell, M. T. \& Kirchman, D. L. (2004). Contribution of SAR11 bacteria to dissolved dimethylsulfoniopropionate and amino acid uptake in the North Atlantic Ocean. Appl Environ Microbiol 70, 4129-4135.

Markert, S., Arndt, C., Felbeck, H., Becher, D., Sievert, S. M., Hügler, M., Albrecht, D., Robidart, J., Bench, S., Feldman, R. A., Hecker, M. \& Schweder, T. (2007). Physiological proteomics of the uncultured endosymbiont of Riftia pachyptila. Science 315, 247-250.

Meyer, B. \& Kuever, J. (2007). Phylogeny of the alpha and beta subunits of the dissimilatory adenosine-5'-phosphosulfate (APS) reductase from sulfate-reducing prokaryotes - origin and evolution of the dissimilatory sulfate-reduction pathway. Microbiology 153, 2026-2044.

Meyer, B., Imhoff, J. F. \& Kuever, J. (2007). Molecular analysis of the distribution and phylogeny of the $\operatorname{sox} B$ gene among sulfur-oxidizing bacteria - evolution of the Sox sulfur oxidation enzyme system. Environ Microbiol (in press).

Molin, S. \& Tolker-Nielsen, T. (2003). Gene transfer occurs with enhanced efficiency in biofilms and induces enhanced stabilisation of the biofilm structure. Curr Opin Biotechnol 14, 255-261.

Muyzer, G., Teske, A., Wirsen, C. O. \& Jannasch, H. W. (1995). Phylogenetic relationships of Thiomicrospira species and their identification in deep-sea hydrothermal vent samples by denaturing gradient gel electrophoresis of $16 \mathrm{~S}$ rDNA fragments. Arch Microbiol 164, 165-172.

Nelson, D. C. \& Fisher, C. R. (1995). Chemoautotrophic and methanoautotrophic endosymbiontic bacteria at deep-sea vents and seeps. In Microbiology of Deep Sea Hydrothermal Vents, pp. 125-167. Edited by D. M. Karl. Boca Raton, FL: CRC Press.

Newton, I. L. G., Woyke, T., Auchtung, T. A., Dilly, G. F., Dutton, R. J., Fisher, M. C., Fontanez, K. M., Lau, E., Stewart, F. J. \& other authors (2007). The Calyptogena magnifica chemoautotrophic symbiont genome. Science 315, 998-1000.

Odintsova, E. V., Wood, A. P. \& Kelly, D. P. (1993). Chemolithoautotrophic growth of Thiothrix ramosa. Arch Microbiol 160, 152-157.

Overmann, J. \& Garcia-Pichel, F. (2001). The phototrophic way of life. In The Prokaryotes an Evolving Electronic Resource for the Microbial Community. Edited by M. Dworkin, E. Falkow, E. Rosenberg, K.-H. Schleifer \& E. Stackebrandt. New York: Fischer Verlag.

Peek, A. S., Vrijenhoek, R. C. \& Gaut, B. S. (1998). Accelerated evolutionary rate in sulfur-oxidizing endosymbiotic bacteria associated with the mode of symbiont transmission. Mol Biol Evol 15, 1514-1523. 
Pires, R. H., Lourenco, A. I., Morais, F., Teixeira, M., Xavier, A. V., Saraiva, L. M. \& Pereira, I. A. C. (2003). A novel membrane-bound respiratory complex from Desulfovibrio desulfuricans ATCC 27774. Bba-Bioenergetics 1605, 67-82.

Pires, R. H., Venceslau, S. S., Morais, F., Teixeira, M., Xavier, A. V. \& Pereira, I. A. C. (2006). Characterization of the Desulfovibrio desulfuricans ATCC 27774 DsrMKJOP complex - a membranebound redox complex involved in the sulfate respiratory pathway. Biochemistry 45, 249-262.

Polz, M. F., Odintsova, E. V. \& Cavanaugh, C. M. (1996). Phylogenetic relationships of the filamentous sulfur bacterium Thiothrix ramosa based on 16S rRNA sequence analysis. Int $J$ Syst Bacteriol 46, 94-97.

Pott, A. S. \& Dahl, C. (1998). Sirohaem sulfite reductase and other proteins encoded by genes at the $d s r$ locus of Chromatium vinosum are involved in the oxidation of intracellular sulfur. Microbiology 144, 1881-1894.

Robertson, L. A. \& Kuenen, G. J. (2001). The genus Thiobacillus. In The Prokaryotes An Evolving Electronic Resource for the Microbial Community. Edited by M. Dworkin, E. Falkow, E. Rosenberg, K.-H. Schleifer \& E. Stackebrandt. New York: Fischer Verlag.

Rohwerder, T. \& Sand, W. (2003). The sulfane sulfur of persulfides is the actual substrate of the sulfur-oxidizing enzymes from Acidithiobacillus and Acidiphilium spp. Microbiology 149, 1699-1710.

Sabehi, G., Loy, A., Jung, K. H., Partha, R., Spudich, J. L., Isaacson, T., Hirschberg, J., Wagner, M. \& Beja, O. (2005). New insights into metabolic properties of marine bacteria encoding proteorhodopsins. PLoS Biol 3, 1409-1417.

Sanchez, O., Ferrera, I., Dahl, C. \& Mas, J. (2001). In vivo role of adenosine-5' -phosphosulfate reductase in the purple sulfur bacterium Allochromatium vinosum. Arch Microbiol 176, 301-305.

Sander, J., Engels-Schwarzlose, S. \& Dahl, C. (2006). Importance of the DsrMKJOP complex for sulfur oxidation in Allochromatium vinosum and phylogenetic analysis of related complexes in other prokaryotes. Arch Microbiol 186, 357-366.

Schedel, M. \& Trüper, H. G. (1980). Anaerobic oxidation of thiosulfate and elemental sulfur in Thiobacillus denitrificans. Arch Microbiol 124, 205-210.

Schiffer, A., Fritz, G., Kroneck, P. M. H. \& Ermler, U. (2006). Reaction mechanism of the iron-sulfur flavoenzyme adenosine- 5 '-phosphosulfate reductase based on the structural characterization of different enzymatic states. Biochemistry 45, 2960-2967.

Simsek, M. \& Adnan, H. (2000). Effect of single mismatches at $3^{\prime}$-end of primers on polymerase chain reaction. Med Sci (Paris) 2, 11-14.
Sorensen, S. J., Bailey, M., Hansen, L. H., Kroer, N. \& Wuertz, S. (2005). Studying plasmid horizontal transfer in situ: a critical review. Nat Rev Microbiol 3, 700-710.

Suzuki, I. (1994). Sulfur-oxidizing enzymes. In Inorganic Microbial Sulfur Metabolism (Methods in Enzymology, 243), pp. 455-462. San Diego, CA: Academic Press.

Takai, K., Campbell, B. J., Cary, S. C., Suzuki, M., Oida, H., Nunoura, T., Hirayama, H., Nakagawa, S., Suzuki, Y. \& other authors (2005). Enzymatic and genetic characterization of carbon and energy metabolisms by deep-sea hydrothermal chemolithoautotrophic isolates of Epsilonproteobacteria. Appl Environ Microbiol 71, 7310-7320.

Taylor, B. F. (1994). Adenylylsulfate reductases from thiobacilli. In Inorganic Microbial Sulfur Metabolism (Methods in Enzymology, 243), pp. 393-400. San Diego, CA: Academic Press.

Teske, A. \& Nelson, D. C. (2004). The genera Beggiatoa and Thioploca. In The Prokaryotes An Evolving Electronic Resource for the Microbial Community. Edited by M. Dworkin, E. Falkow, E. Rosenberg, K.-H. Schleifer \& E. Stackebrandt. New York: Springer Verlag.

Theissen, U., Hoffmeister, M., Grieshaber, M. \& Martin, W. (2003). Single eubacterial origin of eukaryotic sulfide: quinone oxidoreductase, a mitochondrial enzyme conserved from the early evolution of eukaryotes during anoxic and sulfidic times. Mol Biol Evol 20, 1564-1574.

Tonolla, M., Peduzzi, S., Demarta, A., Peduzzi, R. \& Hahn, D. (2004). Phototrophic sulfur and sulfate-reducing bacteria in the chemocline of meromictic Lake Cadagno, Switzerland. Journal of Limnology 63, $161-170$.

Trüper, H. G. \& Fischer, U. (1982). Anaerobic oxidation of sulfurcompounds as electron-donors for bacterial photosynthesis. Philos Trans R Soc Lon B Biol Sci 298, 529-542.

Venter, J. C., Remington, K., Heidelberg, J. F., Halpern, A. L., Rusch, D., Eisen, J. A., Wu, D. Y., Paulsen, I., Nelson, K. E. \& other authors (2004). Environmental genome shotgun sequencing of the Sargasso Sea. Science 304, 66-74.

Visscher, P. T., Prins, R. A. \& van Gemerden, H. (1992). Rates of sulfate reduction and thiosulfate consumption in a marine microbial mat. FEMS Microbiol Ecol 86, 283-294.

Woyke, T., Teeling, H., Ivanova, N. N., Huntemann, M., Richter, M., Gloeckner, F. O., Boffelli, D., Anderson, I. J., Barry, K. W. \& other authors (2006). Symbiosis insights through metagenomic analysis of a microbial consortium. Nature 443, 950-955.

Zimmermann, P., Laska, S. \& Kletzin, A. (1999). Two modes of sulfite oxidation in the extremely thermophilic and acidophilic archaeon Acidianus ambivalens. Arch Microbiol 172, 76-82.

Edited by: G. Muyzer 